\title{
Autochthonous and allochthonous contributions of organic carbon to microbial food webs in Svalbard fjords
}

\author{
Johnna M. Holding, ${ }^{1,2 *}$ Carlos M. Duarte, ${ }^{2,3,4}$ Antonio Delgado-Huertas, ${ }^{5}$ Karline Soetaert, ${ }^{6}$ \\ Jorien E. Vonk, ${ }^{7,8}$ Susana Agustí, ${ }^{3,4}$ Paul Wassmann, ${ }^{4}$ Jack J. Middelburg ${ }^{8}$
}

${ }^{1}$ Department of Global Change Research, Instituto Mediterráneo de Estudios Avanzados (CSIC- Univ. Islas Balears), Esporles, Spain

${ }^{2}$ Arctic Research Centre, Bioscience, Aarhus University, Aarhus C, Denmark

${ }^{3}$ Red Sea Research Center, King Abdullah University of Science and Technology, Thuwal, Kingdom of Saudi Arabia

${ }^{4}$ Faculty of Biosciences, Fisheries and Economics, UiT, The Arctic University of Norway, Tromso, Norway

${ }^{5}$ Laboratorio de Biogeoquímica de Isótopos Estables, Instituto Andaluz de Ciencias de la Tierra (CSIC-Univ. Granada), Granada, Spain

${ }^{6}$ Department of Estuarine and Delta Systems, Royal Netherlands Institute for Sea Research, Yerseke, The Netherlands

${ }^{7}$ Faculty of Earth and Life Science, Department of Earth Sciences, Vrije Universiteit, Amsterdam, The Netherlands

${ }^{8}$ Faculty of Geosciences, Department of Earth Sciences, University of Utrecht, Utrecht, The Netherlands

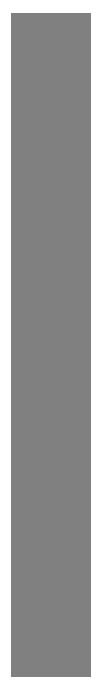

\begin{abstract}
Rising temperatures in the Arctic Ocean are causing sea ice and glaciers to melt at record breaking rates, which has consequences for carbon cycling in the Arctic Ocean that are yet to be fully understood. Microbial carbon cycling is driven by internal processing of in situ produced organic carbon (OC), however recent research suggests that melt water from sea ice and glaciers could introduce an allochthonous source of OC to the microbial food web with ramifications for the metabolic balance of plankton communities. In this study, we characterized autochthonous and allochthonous sources of OC to the Western Svalbard fjord system using stable isotopes of carbon. We quantified $\delta^{13} \mathrm{C}$ of eukaryotic and prokaryotic planktonic groups using polar lipid-derived fatty acids as biomarkers in addition to measuring $\delta^{13} \mathrm{C}$ of marine particulate $\mathrm{OC}$ and dissolved OC from glacial runoff. $\delta^{13} \mathrm{C}$ of bacteria $(-22.5 \%)$ was higher than that of glacial runoff OC $(-28.5 \%)$ and other phytoplankton groups $(-24.7$ to $-29.1 \%$ ), which suggests that marine bacteria preferentially use a third source of OC. We present a Bayesian three-source $\delta^{13} \mathrm{C}$ mixing model whereby $\sim 60 \%$ of bacteria carbon is derived from OC in sea ice, and the remaining carbon is derived from autochthonous production and glacial-derived OC. These results suggest that subsidies of OC from melting glaciers will not likely influence microbial carbon cycling in Svalbard fjords in the future and that further research is needed to determine the effects of melting sea ice on microbial carbon cycling in fjord systems and elsewhere in the Arctic Ocean.
\end{abstract}

The European Arctic Ocean (Barents Sea- Fram StraitGreenland Sea) is responsible for over 50\% of the annual Arctic Ocean primary production (Arrigo et al. 2008; Pabi et al. 2008), most of which occurs over a relatively short period of time starting with the spring bloom (VaquerSunyer et al. 2013) until the end of the summer light period. In the European Arctic Ocean, primary production has been reported to reach up to about $10.3 \mathrm{~g} \mathrm{C} \mathrm{m}^{-2} \mathrm{~d}^{-1}$ during the spring bloom (median: about $3.4 \mathrm{~g} \mathrm{C} \mathrm{m}^{-2} \mathrm{~d}^{-1}$, VaquerSunyer et al. 2013), contributing about $26 \%$ to the annual primary production and supporting most of the annual gross

*Correspondence: johnna.holding@imedea.uib-csic.es community production in the region (Vaquer-Sunyer et al. 2013).

Consequently, high rates of primary production during the spring bloom in the Arctic Ocean are accompanied by high planktonic respiration and bacterial production rates throughout the spring and summer season (Iversen and Seuthe 2011; Vaquer-Sunyer et al. 2013). Therefore, the amount of primary production required to keep microbial plankton communities autotrophic-or threshold primary production-in this region is high relative to other oceans (Duarte and Regaudie-de-Gioux 2009; Vaquer-Sunyer et al. 2013). Meaning any decrease in primary production or increase in planktonic respiration could tip the metabolic balance causing microbial plankton communities to be dominated by heterotrophic metabolism. As the European sector 
of the Arctic Ocean is a hot spot for $\mathrm{CO}_{2}$ uptake in the ocean (Loeng et al. 2005; Hoegh-Guldberg et al. 2014), the possible shift of plankton communities from autotrophic to heterotrophic, i.e., from acting as an atmospheric $\mathrm{CO}_{2}$ sink to source, is of global consequence (Duarte et al. 2012). Experimental research indicates that Arctic planktonic community respiration rates will double with the increase in temperature that is expected with future climate warming, resulting in a switch to heterotrophy beyond $5^{\circ} \mathrm{C}$ (Holding et al. 2013). Furthermore, future warming combined with ice melt is likely to inhibit Arctic primary production due to a strengthening of stratification, isolating the photic layer from turbulent vertical nutrient supply (Wassmann et al. 2008).

Heterotrophic metabolism in planktonic food webs is highly subsidized by allochthonous inputs of organic matter, and this is especially true in the Arctic Ocean due to its semi-enclosed Mediterranean-like basin characteristics (Dietrich et al. 1980). Indeed, high rates of microbial planktonic respiration in the Arctic Ocean are proposed to be caused in part by the high concentrations of dissolved organic matter in the Arctic Ocean basin, due to terrestrial inputs from several large rivers (Duarte and Regaudie-de-Gioux 2009). Hence, an increase in organic carbon availability, especially in combination with increasing temperatures, could enhance microbial respiration rates even further (Pomeroy and Wiebe 2001) favoring heterotrophic metabolism and elevating the amount of primary productivity necessary to maintain net autotrophic metabolism (Duarte and Regaudie-de-Gioux 2009). Increased warming will mobilize organic carbon stocks presently retained on land, through thawing of permafrost and melting of glaciers and ice caps (Duarte et al. 2012), increasing organic carbon availability especially to coastal microbial plankton communities.

Previously, allochthonous organic matter from freshwater entering the marine system has been considered old and therefore resistant to degradation by marine heterotrophs (Raymond and Bauer 2001), however dissolved organic matter (DOM) from glacier melt water has been shown to be a source of ancient but highly labile and bioavailabile organic matter to marine organisms in the Alaskan fjord system (Hood et al. 2009; Fellman et al. 2010). DOM in glacial watersheds is thought to be largely derived from microbial production (Lafrenière and Sharp 2004; Hodson et al. 2005) and wind-borne allochthonous input (Stibal et al. 2008), lacking inputs from higher plants and making it highly labile (McKnight et al. 2001). Hence, in contrast with the understanding of non-glacier watersheds where older DOM is thought to be less labile (Raymond et al. 2007), bioavailability of DOM from Alaskan glaciers is positively correlated to ${ }^{14} \mathrm{C}$ age of DOM, thus more heavily glaciated watersheds are a source of the oldest and, at the same time, most labile DOM (Hood et al. 2009).

The principal goal of this study is to determine whether allochthonous organic matter is a significant carbon source to the microbial food web in the near-shore fjord systems of Western Svalbard with the aim of gaining insight on the consequences of increasing glacier runoff on the metabolic balance of plankton communities in these fjord systems. In contrast to previous studies assessing the role of allochthonous inputs of organic carbon to Arctic microbial food webs (e.g., Hood et al. 2009; Middelboe et al. 2012), our approach involves the assessment of the relative contribution of different organic carbon sources to the microbial food web using compound-specific stable carbon isotope signatures of various plankton groups. While traditionally stable isotope analysis is limited to organisms that can be sorted and analyzed separately, compound specific isotope analysis allows the discrimination of natural abundance of carbon isotopes in complex microbial food webs (Middelburg 2014). Analysis of polar lipid-derived fatty acids (PLFAs) from cell membranes can differentiate prokaryotic and eukaryotic organisms; gram-negative bacteria are easily identified and distinguishable from eukaryotic groups, although the low specificity of PLFAs leads to some crossover between specific phytoplankton groups (Dijkman et al. 2009). While some isotopic fractionation, i.e., the offset of PLFA relative to biomass, should be taken into account (Boschker and Middelburg 2002; Middelburg 2014; Taipale et al. 2015), bacterial PLFA isotope signatures reflect that of their carbon sources (Boschker and Middelburg 2002).

We discriminate between two main sources of dissolved organic matter to the plankton communities in the fjord systems of Western Svalbard: allochthonous organic matter derived from glacier runoff and autochthonous organic matter derived from the photosynthetic activity of both pelagic and ice microalgae. This study took place in late spring/early summer, after the spring bloom, when phytoplankton have exhausted nutrients and $\mathrm{CO}_{2}$ in the water column, been grazed out by zooplankton, or begun to sink to lower depths. At the same time, the glaciers that typically occupy the innermost part of the fjords have initiated their seasonal melt. Thus, we expect that allochthonous, glacier-derived DOM associated with melt water will contribute significantly to the marine organic carbon pool, and if glacial DOM is indeed labile, we would expect Arctic bacterial communities to reflect glacial derived carbon in their isotopic signatures.

\section{Materials and methods}

\section{Study area and sampling}

Samples for this study were taken during a cruise aboard R/V Helmer Hanssen from 11 June 2012 to 17 June 2012 in the coastal fjord system of Western Svalbard. Additionally, we sampled one station from the south of the Svalbard to serve as an open-ocean reference (Fig. 1; Table 1). Sea water samples were collected at a total of nine stations using a Rosette sampling system fitted with a CTD at two depths within the photic layer; the surface layer $(1-5 \mathrm{~m})$ and the 


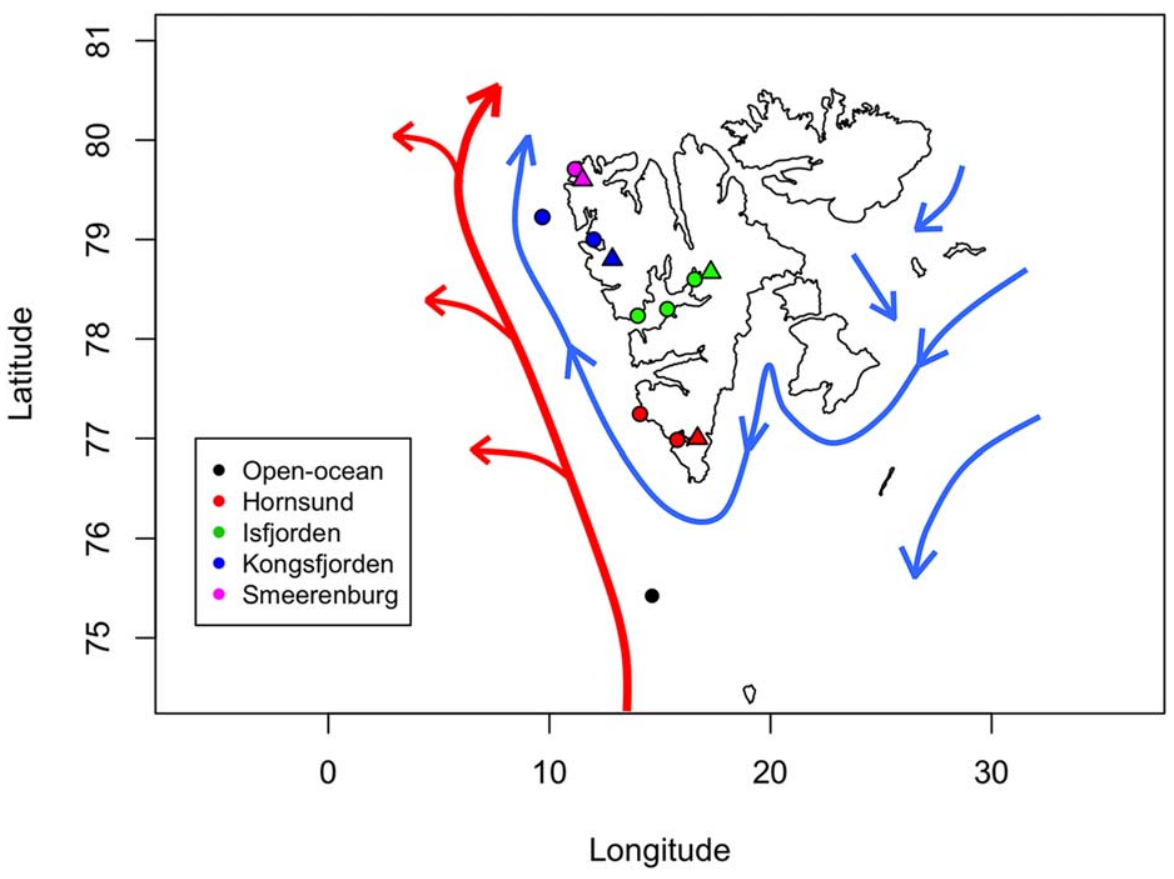

Fig. 1. Map of all stations sampled. Key indicates fjord location. Triangles (or asterisks in non-color version) mark corresponding glacier water stations. Blue arrows (or broken arrows in non-color version) indicate cold, low salinity currents of Arctic origin, while red arrows (or solid arrows in noncolor version) indicate warm, higher salinity currents of Atlantic origin (modified from Svendsen et al. (2002)). See Svendsen et al. (2002) for a more detailed description of physical oceanography of the region. [Color figure can be viewed at wileyonlinelibrary.com]

deep chlorophyll maximum (DCM; 17-34 m). To investigate allochthonous sources of organic matter, glacier runoff water was collected on land in each of the fjords visited (Fig. 1). All carboys used for water collection were previously acid washed $(3.7 \% \mathrm{HCl}$ solution) and rinsed afterward and also pre-rinsed thoroughly with water from the sample site before collection.

\section{Sample Analysis}

Three samples for dissolved organic carbon (DOC) concentration analysis were collected from both glacier and sea water stations. DOC samples were filtered through precombusted $\left(5 \mathrm{~h}, 500^{\circ} \mathrm{C}\right)$ Whatman $\mathrm{GF} / \mathrm{F}$ filters before being syphoned into $10 \mathrm{~mL}$ pre-combusted $\left(5 \mathrm{~h}, 500^{\circ} \mathrm{C}\right)$ glass ampoules. Samples were immediately acidified with $20 \mu \mathrm{L}$ of concentrated phosphoric acid, flame sealed and stored until later analysis. Total DOC concentrations in each sample were determined on a Shimadzu total organic carbon (TOC)5000 or TOC-Vcsh following high-temperature catalytic oxidation techniques (Spyres et al. 2000).

Two $50 \mathrm{~mL}$ samples for chlorophyll $a(\mathrm{Chl} a)$ determination were collected from all seawater stations, filtered through Whatman GF/F filters, and frozen until later analysis. Chl $a$ concentration was determined fluorometrically following extraction of the filters in 90\% acetone for $24 \mathrm{~h}$ (Parsons et al. 1984). Two $10 \mathrm{~mL}$ samples for nutrient analysis were collected from both glacier and seawater stations and kept frozen until analysis. Phosphorus, nitrate+nitrite, and silicate concentrations were analyzed using standard methods (Hansen and Koroleff 1999) in a Bran Luebe AA3 autoanalyzer.

Two $10 \mathrm{~mL}$ samples for bacterial abundance (BA) counts were collected from both glacier and seawater stations and fixed with formalin (final concentration 2\%) until analysis. Samples were filtered through $0.2 \mu \mathrm{m}$ black polycarbonate filters and stained with DAPI (4,6-diamidino-2-phenylindole; Porter and Feig 1980) to a final concentration of $5 \mu \mathrm{g} \mathrm{m} \mathrm{L}{ }^{-1}$ (Sieracki et al. 1985). Bacteria were counted using epifluorescence microscopy (Olympus BX40-102/E, at 1000X) by selecting 20 fields per sample. Fields were selected only when 20 or more bacteria were visible, thus counting at least 400 bacteria per sample. Counts were then extrapolated to the entire sample.

\section{Carbon isotope analysis}

Two liters of water were collected at each seawater station and depth to measure polar lipid fatty acid (PLFA) and particulate organic ${ }^{13} \mathrm{C}$-carbon (POC) content. A known amount of sample was filtered through two pre-combusted $(5 \mathrm{~h}$, $500^{\circ} \mathrm{C}$ ) Whatman $\mathrm{GF} / \mathrm{F}$ filters which were dried and frozen until later analysis. One quarter of one of the replicate filters was used to measure ${ }^{13} \mathrm{C}$ concentrations of $\mathrm{POC}$ via a Thermo Electron Flash EA 1112 analyser (EA) coupled to a Delta V isotope ratio mass spectrometer (IRMS). Lipids were extracted from the remaining filters using the Bligh-Dyer method (Bligh and Dyer 1959; Boschker et al. 1998) and 


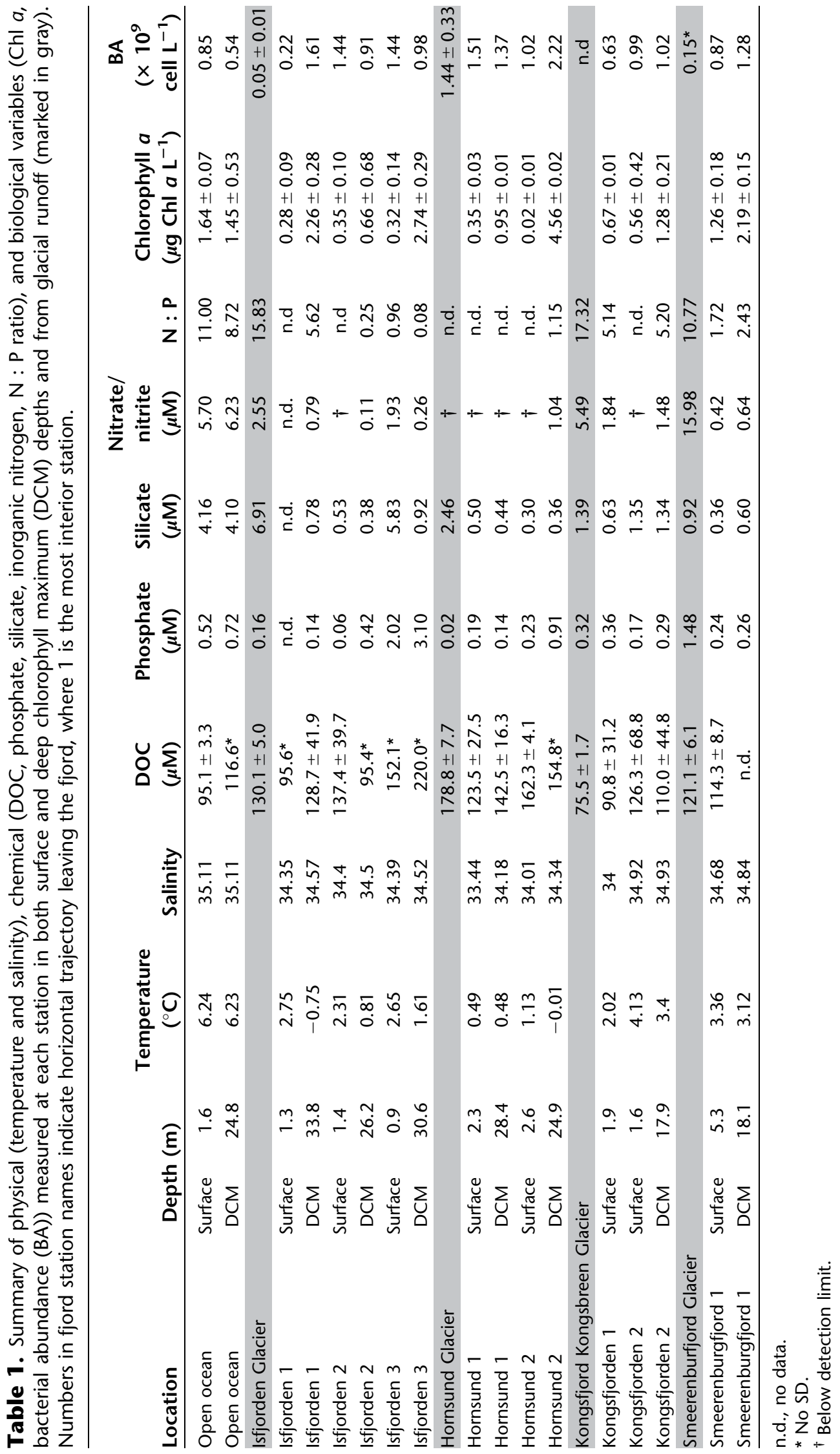


fractionated in different polarity classes by column separation on a heat-activated-silicic acid column and subsequent elution with chloroform, acetone, and methanol. The methanol fractions, containing most of the PLFAs, were derivatized using mild alkaline methanolysis to yield fatty acid methyl esters (FAME). PLFA concentrations were determined by gas chromatograph-flame ionization detection (GC-FID) and identification was based on retention times and verified with gas chromatography-mass spectrometry (GC-MS). The $\delta^{13} \mathrm{C}$ of individual PLFAs were measured using gas chromatography-combustion isotope ratio mass spectrometry (GC-C-IRMS; Middelburg et al. 2000; Van den Meersche et al. 2009).

Samples for glacier dissolved organic carbon (DOC) isotopes were filtered through pre-combusted $\left(5 \mathrm{~h}, 500^{\circ} \mathrm{C}\right)$ Whatman GF/F filters before being syphoned into $4-30 \mathrm{~mL}$ precombusted $\left(5 \mathrm{~h}, 500^{\circ} \mathrm{C}\right)$ glass ampoules. Samples were immediately acidified with $40 \mu \mathrm{L}$ of concentrated phosphoric acid, and stored until later analysis. Carbon isotope composition was measured via liquid chromatography-microcombustion isotope ratio mass spectrometry (LC-IRMS).

\section{Data analysis}

Carbon stable isotope ratios are expressed in the delta notation relative to Vienna Pee Dee Belemnite (VPDB) standard $\left(\delta^{13} \mathrm{C}\right.$ in $\left.\%\right)$. As certain PLFAs can serve as biomarkers within the marine microbial community (Boschker and Middelburg 2002) we averaged specific PLFA values to distinguish between different groups in the following manner. The PLFAs iC14:0, iC15:0 and aiC15:0 were used to characterize heterotrophic bacteria, henceforth "bacteria" (Table 2; Boschker and Middelburg 2002). Carbon isotope signatures of algal PLFA's have some overlap, but general distinctions can be made between algal groups. To answer the hypothesis of this study it would be sufficient to distinguish simply between phytoplankton and bacteria, however as we noticed variation in $\delta^{13} \mathrm{C}$ among fatty acids, which can represent certain functional groups, we decided to create two main groups of phytoplankton as in de Kluijver et al. (2013) which was carried out in the same region as this study (Table 2). The average of the PLFAs C22:6 03 and C20:5 $\omega 3$ are hereafter referred to as "phyto a," and are characteristic to heterotrophic dinoflagellates and diatoms, respectively (Viso and Marty 1993; Dijkman and Kromkamp 2006; Dijkman et al. 2009), although C22:6 63 can also be characteristic of haptophytes and C20:5 $\omega 3$ can also include rhodophytes and some cryptophytes (Dijkman and Kromkamp 2006). The average of PLFAs C18:3 $\omega 3, \mathrm{C} 18: 5 \omega 3$, and $\mathrm{C} 18: 4 \omega 3$ are hereafter "phyto b" (Table 2) and generally correspond to chlorophytes (Viso and Marty 1993; Dijkman and Kromkamp 2006; Dijkman et al. 2009) but can also include cryptophytes and autotrophic dinoflagellates (Dijkman and Kromkamp 2006; Dijkman et al. 2009). In order to characterize the autochthonous end-member "phytoplankton," we averaged $\delta^{13} \mathrm{C}$ values of PLFAs from both phyto a and phyto b, as has was done by de Kluijver et al. (2010, 2013). We considered a range of values for fatty acid fractionation relative to biomass: $0-3 \%$ for bacteria and 2-5\% for phytoplankton (Abraham et al. 1998; Boschker et al. 1999; Boschker and Middelburg 2002; Bouillon and Boschker 2006; Middelburg 2014; Taipale et al. 2015) which are applied during analyses where mentioned. Statistical tests were performed using both the statistical program JMP and the statistical software R@ (R Core Team 2014).

\section{Literature meta-analysis}

We performed a thorough literature search to locate published values of $\delta^{13} \mathrm{C}$ of various end-members in the Svalbard fjords and Barents Sea region. We found 19 values for phytoplankton and particulate organic matter (POM), four values for glacier or terrestrial run-off, and 19 values for ice algae and ice POM in the region (Table 3). Additionally, we found one value for sediment $\mathrm{OM}$ and one value for POM from drifting icebergs. Ice algae and ice POM values were used to characterize the ice algae end-member in the mixing model (see below).

\section{Stable isotope mixing model}

A three end-member Bayesian mixing model was applied to the carbon stable isotope data to investigate the proportional contribution of autochthonous (phytoplankton and ice algae) and allochthonous (glacier DOC) sources to the stable isotope composition of bacteria. The $\mathrm{R}$ software package SIAR (Stable Isotope analysis in R; Parnell et al. 2008) was used as it was designed, to solve stable isotope mixing problems that take into account variation in both the sources and fractionation factors, as well as to cope with multiple sources, by applying Markov chain Monte Carlo (MCMC) algorithms (Parnell et al. 2010). As there was no difference in bacterial carbon isotope signatures across fjords (see Results), all bacterial data were treated as one group for the analysis, and 500,000 model iterations were run. Assuming normal distribution of the range of fractionation factors from the literature (see above), we applied an average fractionation factor $( \pm \mathrm{SD})$ of bacteria $(1.5 \pm 0.86 \%$ ) to all the sources in the analysis by including it as a "trophic enrichment factor" in the model input (See Parnell et al. 2008). In order to take into account the fractionation during fatty acid synthesis of the phytoplankton source we applied an additional factor of $3.5 \%$ to the phytoplankton source values; again we assumed a normal distribution of the range of fractionation factors from the literature (see above), and we propagated the standard error term $(0.86 \%)$ of this range to the error in the source values.

\section{Results}

The photic layer in the open-ocean station appeared to be well mixed, and both temperature and salinity were highest 


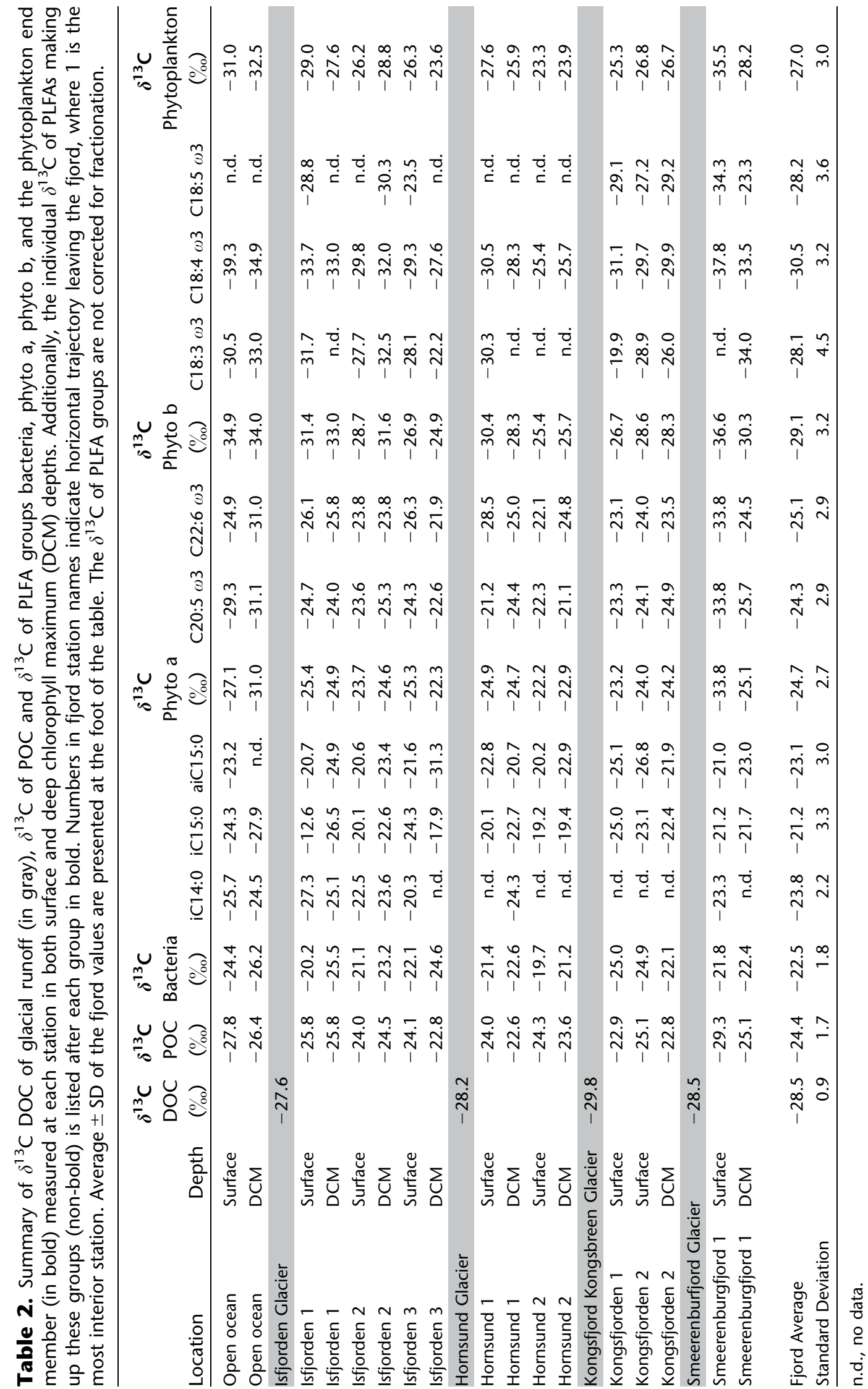


Table 3. Summary of $\delta^{13} \mathrm{C}$ (mean \pm SD) values from possible sources of organic carbon in the Barents Sea- Fram Strait- Western Svalbard fjord system from literature, where $n$ is the number of values included in the mean. All values from sea ice were used as the sea ice algae end member unless otherwise indicated.

\begin{tabular}{|c|c|c|c|c|c|c|c|}
\hline Source & Season & Latitude & Longitude & $\begin{array}{c}\text { Mean }( \pm S D) \\
\delta^{13} C \\
\end{array}$ & $n$ & Source detail & Reference \\
\hline Sea Ice & Spring & Barents Sea & & -15.7 & 1 & Ice Algae & McMahon et al. (2006) \\
\hline Sea Ice & Spring & Barents Sea & & $-21.9^{*} \ddagger$ & 1 & Sea Ice C20:5 $\omega 3$ & McMahon et al. (2006) \\
\hline Sea Ice & Spring & $75-77^{\circ} \mathrm{N}$ & $27-34^{\circ} \mathrm{E}$ & -19.9 & 1 & Obligate Ice POM & Søreide et al. (2006) \\
\hline Sea Ice & Spring & $80^{\circ} \mathrm{N}$ & $22^{\circ} \mathrm{E}$ & $-21.9 \pm 1.1^{\dagger}$ & 3 & Ice Algae & Leu et al. (2010) \\
\hline Sea Ice & Summer & $75-79^{\circ} \mathrm{N}$ & $25-30^{\circ} \mathrm{E}$ & $-18.7 \pm 3.9$ & 5 & Ice POM & Tamelander et al. (2006a) \\
\hline Sea Ice & Summer & $80-83^{\circ} \mathrm{N}$ & $0-30^{\circ} \mathrm{N}$ & $-20.4 \pm 2.3$ & 4 & Ice core (lower portion) & Schubert and Calvert (2001) \\
\hline Sea Ice & Summer & & & -19.0 & 1 & Obligate Ice POM & Søreide et al. (2006) \\
\hline Sea Ice & Summer & $81^{\circ} \mathrm{N}$ & $25^{\circ} \mathrm{E}$ & -20.0 & 1 & Obligate Ice POM & Søreide et al. (2006) \\
\hline Sea Ice & Summer & $80^{\circ} \mathrm{N}$ & $22^{\circ} \mathrm{E}$ & $-17.4 \pm 0.4$ & 2 & Ice Algae & Leu et al. (2010) \\
\hline Phytoplankton & Spring & Barents Sea & & -24.5 & 1 & Phytoplankton & McMahon et al. (2006) \\
\hline Phytoplankton & Spring & Barents Sea & & $-32^{*}$ & 1 & Phytoplankton C20:5 $\omega 3$ & McMahon et al. (2006) \\
\hline POM & Spring & $75-82^{\circ} \mathrm{N}$ & $16-40^{\circ} \mathrm{E}$ & $-21.6 \pm 1.6$ & 4 & POM & Tamelander et al. (2009) \\
\hline POM & Spring & $75-77^{\circ} \mathrm{N}$ & $27-34^{\circ} \mathrm{E}$ & $-24.1 \pm 0.6$ & 2 & Pelagic POM & Søreide et al. (2006) \\
\hline POM & Summer & $79^{\circ} \mathrm{N}$ & $12^{\circ} \mathrm{E}$ & $-25.8 \pm 0.2$ & 3 & Marine POM & Kuliński et al. (2014) \\
\hline POM & Summer & $75-82^{\circ} \mathrm{N}$ & $16-40^{\circ} \mathrm{E}$ & $-25.6 \pm 1.5$ & 8 & POM & Tamelander et al. (2009) \\
\hline Sediment OM & Summer & $79^{\circ} \mathrm{N}$ & $12^{\circ} \mathrm{E}$ & $-22.5 \pm 0.2$ & 3 & Marine sediment & Kuliński et al. (2014) \\
\hline Glacier & Summer & $79^{\circ} \mathrm{N}$ & $12^{\circ} \mathrm{E}$ & -25.1 & 1 & Kongsbreen glaciar discharge & Kuliński et al. (2014) \\
\hline Glacier run-off & Summer & $79^{\circ} \mathrm{N}$ & $12^{\circ} \mathrm{E}$ & -25.4 & 1 & Bayelva River & Kuliński et al. (2014) \\
\hline Terrestrial run-off & Summer & $79^{\circ} \mathrm{N}$ & $12^{\circ} \mathrm{E}$ & -26.7 & 1 & NyLondon river & Kuliński et al. (2014) \\
\hline Terrestrial run-off & Summer & $79^{\circ} \mathrm{N}$ & $12^{\circ} \mathrm{E}$ & -26.6 & 1 & Stream leaving bird colony & Kuliński et al. (2014) \\
\hline Iceberg POM & Summer & $79^{\circ} \mathrm{N}$ & $12^{\circ} \mathrm{E}$ & -24.4 & 1 & Drifting icebergs & Kuliński et al. (2014) \\
\hline
\end{tabular}

* Does not include PLFA fractionation factor.

† Values not included in analysis as they were measured in early spring.

¥ Values not included in analysis due to PLFA fractionation.

in this location (Table 1). In contrast the fjord stations appeared to be strongly stratified (Table 1), with warmer (by, on average, $1.17^{\circ} \mathrm{C}$ ) and fresher (by, on average, 0.24 units) waters in surface compared to DCM layers in the fjord stations visited (t-test: $p=0.04$ for temperature and salinity). Temperature and salinity were positively correlated to each other across all stations sampled $(r=0.71)$, and both salinity and temperature tended to increase with latitude in the fjord system ( $r=0.71,0.75$, respectively; Fig. 2a). Nutrient concentrations varied among stations (Table 1) but no trend with latitude, temperature, or salinity was detected. Paired $t$-tests did not indicate significant differences of nutrient concentrations between surface and DCM layers. The open-ocean station had much higher mean $( \pm$ SD) silicate $(4.1 \pm 0.04 \mu \mathrm{mol}$ $\left.\mathrm{Si} \mathrm{L}^{-1}\right)$ and inorganic nitrogen $\left(6.0 \pm 0.4 \mu \mathrm{mol} \mathrm{N} \mathrm{L}{ }^{-1}\right)$ concentrations than the fjord stations (silicate: $1.0 \pm 1.4 \mu \mathrm{mol} \mathrm{Si}$ $\mathrm{L}^{-1}$; inorganic nitrogen: $0.6 \pm 0.7 \mu \mathrm{mol} \mathrm{N} \mathrm{L}{ }^{-1}$ ), while phosphate concentrations were similar in open-ocean and fjord stations (mean $\pm \mathrm{SD}$ in all stations: $0.6 \pm 0.8 \mu \mathrm{mol} \mathrm{P} \mathrm{L}^{-1}$ ). DOC concentrations were also variable among stations (Table 1 ; mean \pm SD: $129.1 \pm 33.1 \mu \mathrm{M}$ ), with no apparent trend with latitude, temperature, or salinity, and no significant difference between surface and DCM layers.
Nutrient concentrations varied greatly among glaciers (Table 1). In general, inorganic nitrogen concentrations from glacier sources were much higher than those in adjacent fjord waters (Table 1) while phosphate concentrations were variable but often lower in the glacier water than in the adjacent fjord waters, resulting in consistently higher $\mathrm{N}: \mathrm{P}$ ratios in glacier water compared to the fjord (Table 1). $\mathrm{N}$ : P ratios were also higher in the open-ocean station (Table 1) compared with fjord water stations. DOC concentrations in glacier runoff waters were highly variable and not necessarily higher than their fjord station counterparts, particularly in the case of Kongsfjorden glacier runoff that had particularly low DOC concentrations (Table 1).

Chl $a$ concentrations varied across all stations (Table 1) with a mean $( \pm \mathrm{SD})$ of $0.6 \pm 0.6 \mu \mathrm{g}$ Chl $a \mathrm{~L}^{-1}$ in surface waters and $2.0 \pm 1.4 \mu \mathrm{g}$ Chl $a \mathrm{~L}^{-1}$ in DCM layers (paired $t$ test: $p=0.03)$. Bacterial abundance (BA) also varied across all stations (Table 1 ; mean \pm SD: $1.1 \pm 0.5 \times 10^{9}$ cells $\mathrm{L}^{-1}$ ), but there was no difference in BA in surface vs. DCM layers. BA decreased with increasing temperature $(r=-0.58)$, but Chl $a$ and BA did not covary with each other or with salinity, nutrients, and DOC concentrations. BA was variable in glacier runoff water but on average about half that of fjord 

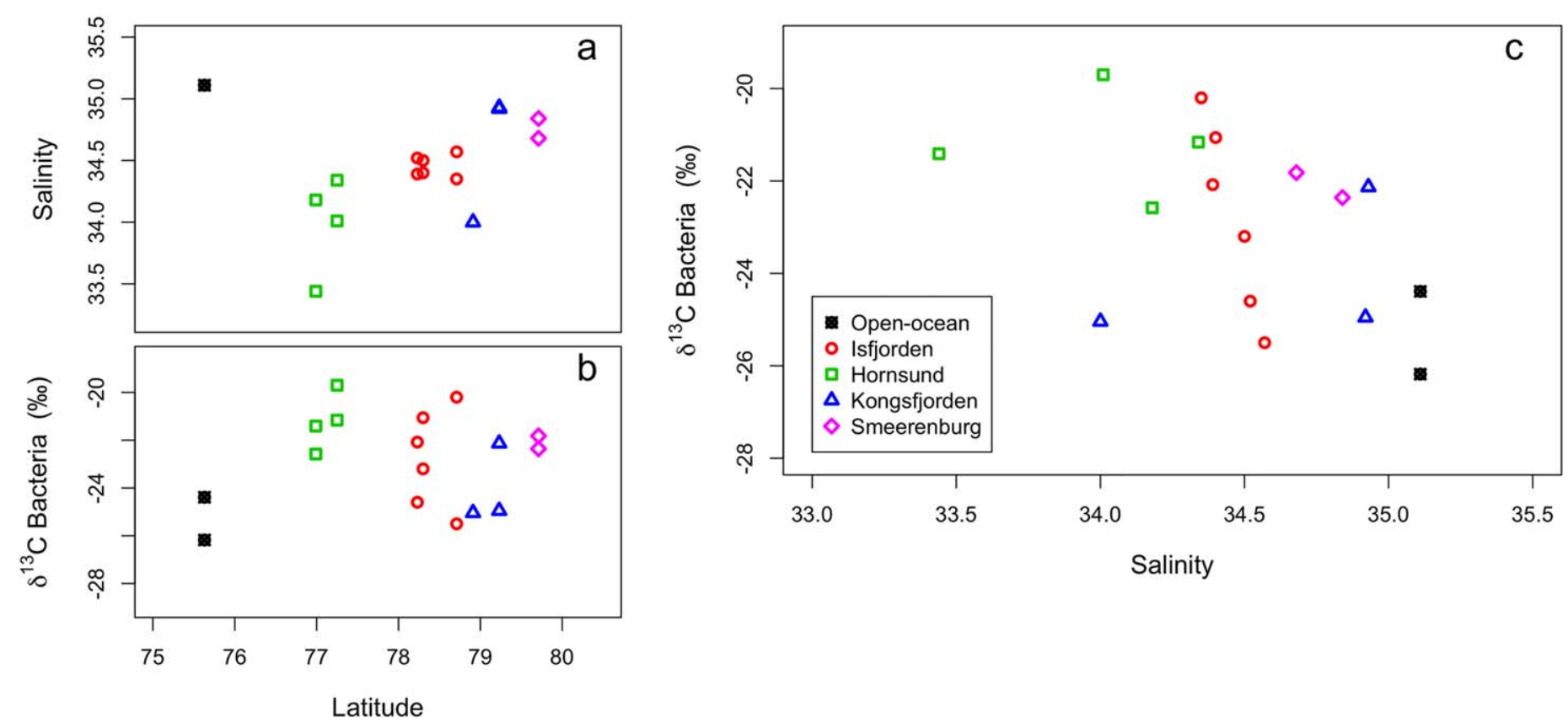

Fig. 2. Scatter plots showing the correlation of salinity with latitude $(\mathbf{a}), \delta^{13} \mathrm{C}$ of bacteria PLFA (not corrected for fatty acid fractionation) with latitude (b), and $\delta^{13} \mathrm{C}$ of bacteria PLFA (not corrected for fatty acid fractionation) with salinity for each station (c). The key in panel $\mathbf{c}$, indicating fjord location, applies to all panels. [Color figure can be viewed at wileyonlinelibrary.com]

waters (Table 1 ; glacier mean $\pm \mathrm{SD}$ : $0.6 \pm 0.8 \times 10^{9}$ cells $\mathrm{L}^{-1}$; fjord mean \pm SD: $1.1 \pm 0.5 \times 10^{9}$ cells $\mathrm{L}^{-1}$ ).

We report $\delta^{13} \mathrm{C}$ of POC along with ${ }^{13} \mathrm{C}$ ratios from PLFAs, which were grouped in three groups as indicated in the methods: bacteria, phyto a, and phyto $b$ (Table 2). A combination of phyto a and phyto $b$ values was used to represent the phytoplankton end-member (see Methods; Table 2). $\delta^{13} \mathrm{C}$ values of POC and PLFAs were independent of the depth layer sampled. $\delta^{13} \mathrm{C}$-bacteria, from all stations, was weakly correlated with salinity $(r=-0.47$; Fig. $2 c)$, with bacteria from fjord stations being more depleted in ${ }^{13} \mathrm{C}$ with increasing latitude ( $r=-0.35$, Fig. 2b). $\delta^{13} \mathrm{C}$-bacteria in the open-ocean station (Mean \pm SD: $-25.5 \pm 1.3 \%$ ) was much lower than the average $\delta^{13} \mathrm{C}$-bacteria in the fjord stations $(-22.5 \pm 1.8 \%$ ). $\delta^{13} \mathrm{C}$ of POC, phyto a, phyto $\mathrm{b}$, and the combined phytoplankton groups, were also weakly correlated to salinity $(r=-0.47,-0.42,-0.43,-0.46$, respectively; Fig. 3). Examination of the relationship between $\delta^{13} \mathrm{C}$ PLFA group values (after average fractionation factors were applied; see Methods) and $\delta^{13} \mathrm{C}$ of POC from all stations allows us to visualize which groups are most responsible for the ${ }^{13} \mathrm{C}$ signature of POC by how close the points from each group are to a $1: 1$ line (Fig. 4). From this figure, it is clear that none of the PLFA groups are solely responsible for the POC signature, however it may be best explained by the average of the phyto a and phyto $\mathrm{b} \delta^{13} \mathrm{C}$ values, which we have called "phytoplankton" (see Methods). This alignment of the phytoplankton and POC $\delta^{13} \mathrm{C}$ values gives us increased justification for using "phytoplankton" as the autochthonous end member.

We averaged $\delta^{13} \mathrm{C}$ values of each group across all fjord stations (i.e., not including the open-ocean station) to test for differences between groups (Table 2; Fig. 5). In Fig. 5, we present the range of values for PLFAs including both their maximum and minimum fractionation factors (see Methods), however we only used average fractionation factors for the PLFA groups $-1.5 \%$ for bacteria and $3.5 \%$ for phyto a, phyto $b$, and phytoplankton (see Methods) - in the analysis of variance. The analysis of variance test revealed significant differences between groups $(F=15.6, p<0.001)$. Glacier DOC is significantly depleted in ${ }^{13} \mathrm{C}$ compared to bacteria, phyto a, and ice algae (Tukey's HSD: $p<0.05$ in all group comparisons) with differences ranging from $9.5 \%$ with bacteria to $7.3 \%$ with phyto a (Fig. 5). Phyto a and phyto $b$ are significantly different from one another (Tukey's HSD: $p=0.0002$ ); phyto b values are significantly different than bacteria and ice algae (Tukey's HSD: $p<0.0001$ for both comparisons) however phyto a are not different from either (Fig. 5). As phytoplankton values are an average of phyto a and phyto $b$ values, they are not significantly different than either, but phytoplankton values are significantly different from ice algae and glacier DOC (Fig. 5; Tukey's HSD; $p=0.0001$ and 0.01 , respectively) with differences of $4.5 \%$ and $5.1 \%$, respectively, thus allowing for three isotopically distinct sources of carbon. $\delta^{13} \mathrm{C}$ of POC is significantly different from $\delta^{13} \mathrm{C}$ of phyto a, bacteria, and ice algae (Fig. 5; Tukey's HSD: $p>0.05$ for all group comparisons). 


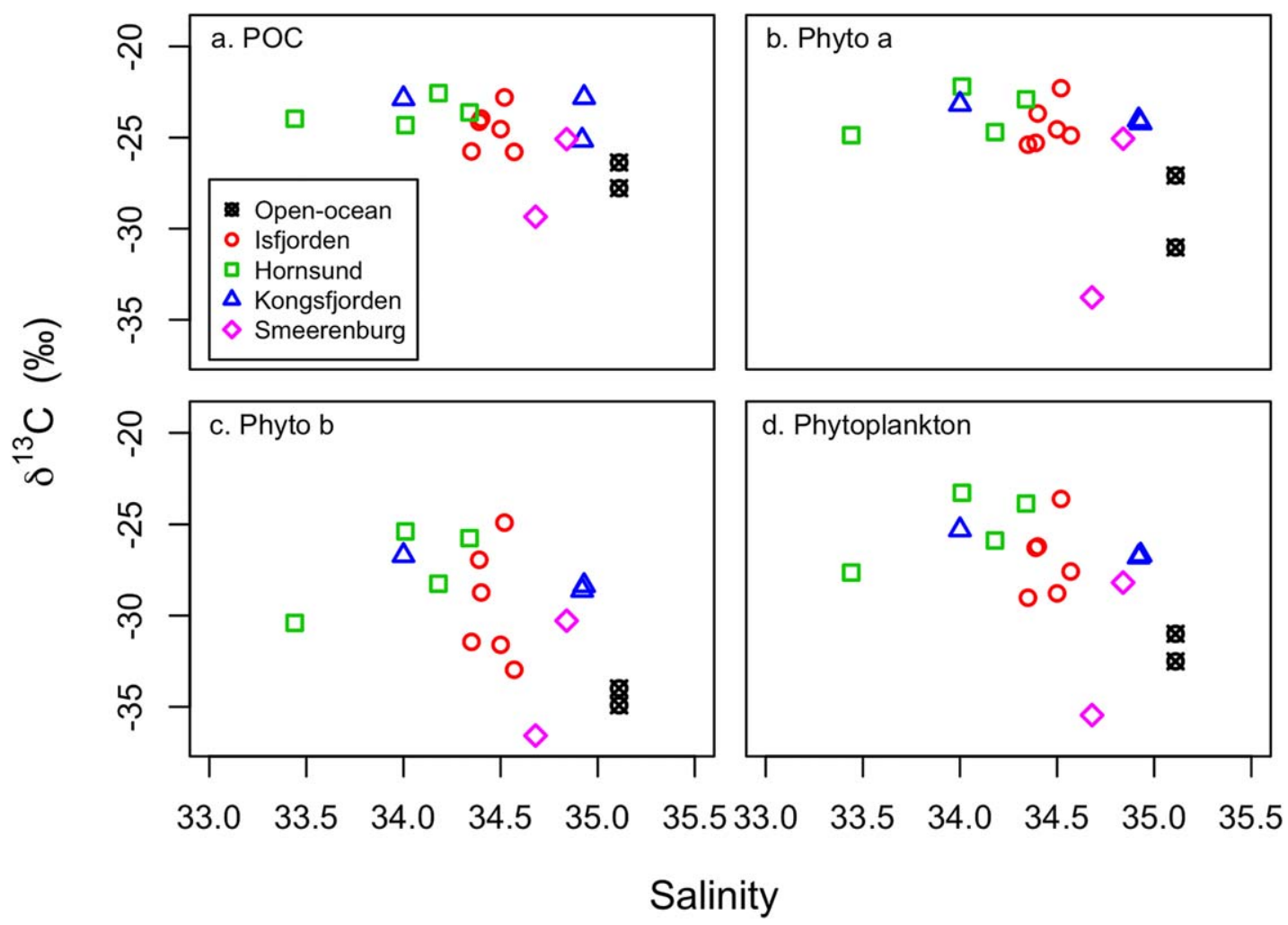

Fig. 3. Scatter plots showing the correlation of $\delta^{13} \mathrm{C}$ to salinity for $\mathrm{POC}(\mathbf{a})$, phyto b (b), phyto a (c), and the phytoplankton end member (d). The key in panel $\mathbf{a}$, indicating fjord location, applies to all panels. [Color figure can be viewed at wileyonlinelibrary.com]

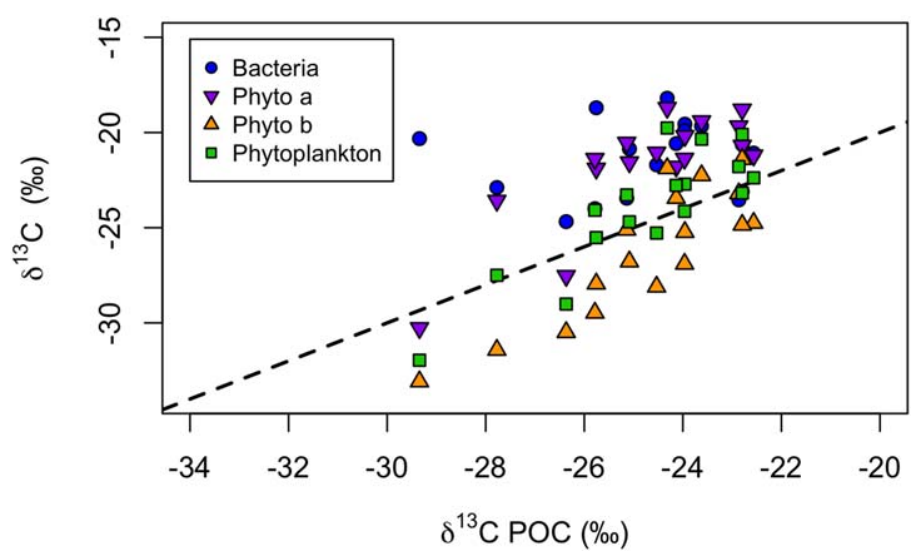

Fig. 4. $\delta^{13} \mathrm{C}$ of bacteria, phyto $\mathrm{a}$, phyto $\mathrm{b}$, and the phytoplankton end member all corrected for average fractionation values (see Methods; symbol code indicated in legend) vs. $\delta^{13} \mathrm{C}-\mathrm{POC}$ at all stations sampled. Dashed black line is the $1: 1$ line. [Color figure can be viewed at wileyonlinelibrary.com]

The relative contribution of the different carbon sources to bacteria was assessed using a Markov chain Monte Carlo Bayesian mixing model (see Methods). The three sources included in the model are: (1) phytoplankton, represented by the average $\pm \mathrm{SD} \delta^{13} \mathrm{C}$ values of phyto a and phyto $\mathrm{b}$ from fjord stations $(-27.0 \pm 1.7 \% ; n=15)$ which, after adding and propagating the error of the average \pm SD PLFA fractionation correction factor $(3.5 \pm 0.86 \%$; see Methods) resulted in an average \pm SD of $-23.5 \pm 3.1 \%$, (2) ice algae, represented by the average $\pm \mathrm{SD}$ of $15 \delta^{13} \mathrm{C}$ values of ice algae or ice POM measured in Barents Sea-Fram Strait and Svalbard fjords regions in the spring and summer $(-19.0 \pm 2.7 \%$; Table 3$)$, and (3) glacier DOC, represented by the average \pm SD of $\delta^{13} \mathrm{C}$ values from the four glaciers measured in this study (Table 2; $-28.5 \pm 0.9 \%$ ). The model, which was run for 500,000 iterations of which the first 50,000 were excluded, estimates the mean \pm SD contribution of the various organic carbon sources to bacterial carbon to be $30.3 \% \pm 14.7 \%$ from phytoplankton, $10.8 \% \pm 7.2 \%$ from glacier DOC, and $58.9 \% \pm$ $10.5 \%$ from ice algae (Fig. 6).

\section{Discussion}

This study encompassed a range of physical conditions, from a well-mixed station in the open-ocean south of the Svalbard archipelago to several fjord systems where fresher and cooler waters result in strong stratification (Table 1). The physical conditions in the open-ocean station are likely due to the influence of warm Atlantic waters entering via the West Spitsbergen Current resulting in earlier blooms and strong mixing before temperature stratification occurs later 


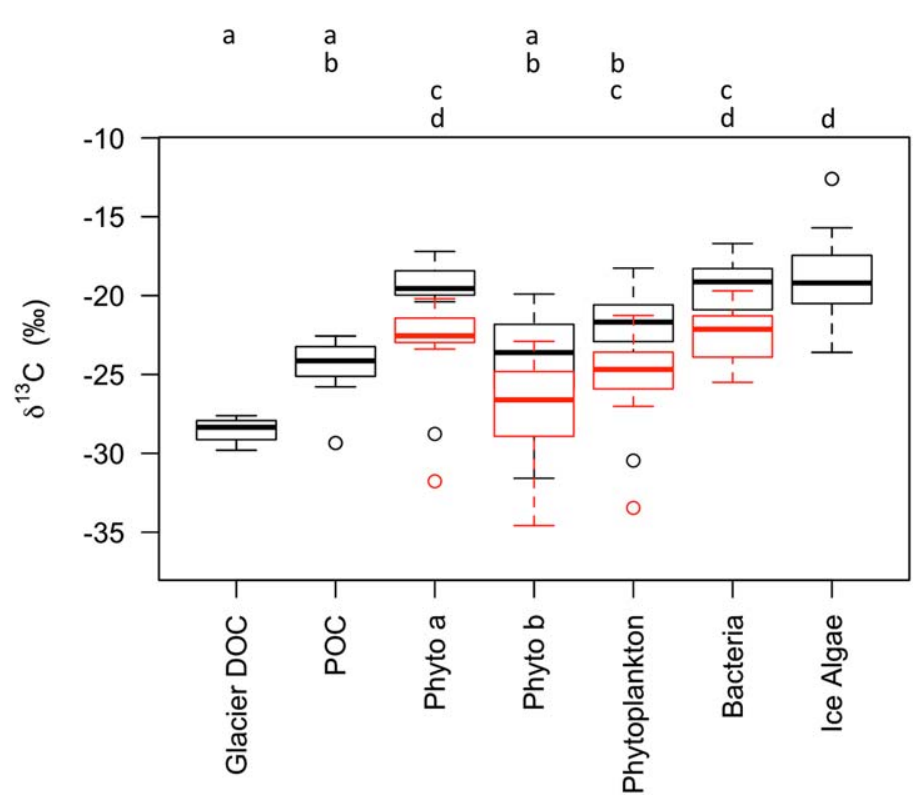

Fig. 5. Box plot of median, and 68 and 95 percentile $\delta^{13} \mathrm{C}$ for groups labeled on the $x$-axis. Open circles represent outliers. Overlaying box and whiskers in the phyto a, phyto $b$, phytoplankton, and bacteria groups represent the range when the appropriate maximum (black) and minimum (red or gray in non-color version) fatty acid fractionation correction factor for each group is applied (see Methods). Letters at the top of the plot indicate the groupings based on Tukeys HSD post hoc test where average fractionation values were applied (see Results for more detail of this analysis). [Color figure can be viewed at wileyonlinelibrary.com]

in the summer (Ingvaldsen and Loeng 2009). The Western Svalbard fjord systems, however, are influenced by both freshwater runoff from land and exchange processes with cold and low saline waters of Arctic origin-those from the Spitsbergen Coastal Current which flow southward along eastern Svalbard and turn northward around the southern tip of the archipelago to eventually mix with warmer Atlantic waters in the North of Svalbard (Fig. 1; Svendsen et al. 2002), reflected in the positive temperature and salinity trends with increasing latitude that we find in this study. Mixing of Arctic and Atlantic water invading Svalbard fjords, combined with freshwater runoff and ice melting explains the strong stratification found in the fjord stations (Table 1), characteristic of the Western Svalbard Fjord system (Svendsen et al. 2002; Piwosz et al. 2009).

Despite differences in water-column stratification in the fjord stations vs. the open-ocean stations, there were no apparent differences between autotrophic and heterotrophic bacterial plankton abundance across stations. Overall, $\mathrm{Chl} a$ values were low across all stations $\left(0.02-4.56 \mu \mathrm{g} \mathrm{Chl} a \mathrm{~L}^{-1}\right.$; Table 1) indicating in most cases a post-bloom scenario. This range encompasses average $\mathrm{Chl} a$ values previously reported in May and July in Kongsfjorden $\left(0.18 \mu \mathrm{g} \mathrm{Chl} a \mathrm{~L}^{-1}\right.$ and 1.02 $\mu \mathrm{g}$ Chl $a \mathrm{~L}^{-1}$, respectively) and is lower than the average concentration found during the spring bloom in April (9.87

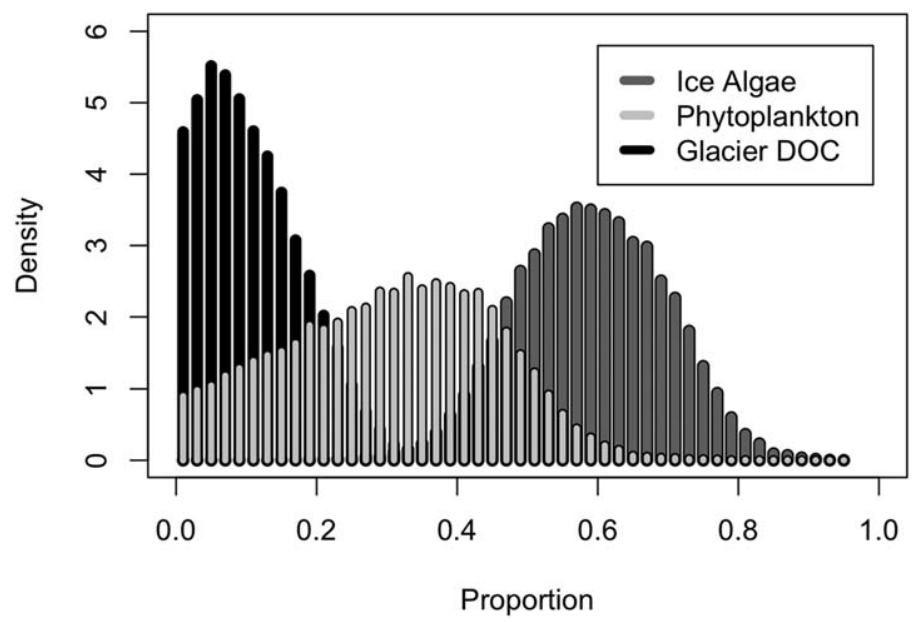

Fig. 6. Results from a triple source stable isotope mixed model simulation for bacterial PLFA $\delta^{13} \mathrm{C}$ values. For the Glacial DOM source we used the average of $\delta^{13} \mathrm{C}$ values measured in the four the glaciers visited $(-28.5 \pm 0.9 \%)$. For the phytoplankton source we used an average \pm SD of $\delta^{13} \mathrm{C}$ PLFA of phyto a and phyto $\mathrm{b}$ values after applying and propagating the error of the average fractionation factor (see Methods and Results for further details; $-23.5 \pm 3.1 \%$ ), and the ice algae source was based on the average of $\delta^{13} \mathrm{C}$ values $(n=15)$ from the literature $(-19.0 \pm 2.7 \%)$. The average \pm SD of the bacterial fractionation factor $(-1.5 \pm 0.87 \%$ ) was applied to all sources in the model (see Methods and Results for details). The key indicates the colors of the corresponding source histogram, each of which shows the probability density for the proportion contribution to the bacterial carbon isotope signature (01) after 500,000 model iterations.

$\mu \mathrm{g} \mathrm{Chl} a \mathrm{~L}^{-1}$; Iversen and Seuthe 2011). The range of bacterial abundance we report $\left(0.22-2.22 \times 10^{9}\right.$ cells $\left.\mathrm{L}^{-1}\right)$ is similar to that previously reported in Kongsfjorden in August (0.6$2.2 \times 10^{9}$ cells L $^{-1}$, Wang et al. 2009), but lower than the post bloom abundance found reported in Kongsfjorden in May and July (4.36 and $3.28 \times 10^{9}$ cells $\mathrm{L}^{-1}$ respectively; Iversen and Seuthe 2011). Iversen and Seuthe (2011) observe that in terms of carbon, bacterial biomass is consistently higher than autotrophic biomass in the months following a bloom, and in terms of metabolic activity the difference between bacterial production and autotrophic production is much smaller after the bloom, indicating a prominence of heterotrophic communities and possible limitation of carbon and/or nutrients to heterotrophic communities (Seuthe 2011). In fact, several studies from Arctic fjords indicate that heterotrophic bacteria are indeed limited by organic carbon following the spring bloom (Møller and Nielsen 2000; Thingstad et al. 2002).

As post-bloom autotrophic biomass is not sufficient to supply carbon to prokaryotic production, it is during this post-bloom period when heterotrophic bacteria are likely dependent on another organic carbon source rather than new autotrophic production in the system. Growing evidence in the literature points to melt water from glacier sources as an allochthonous source of ancient, but highly 
bioavailable, organic matter to the microbial food web (Hood et al. 2009; Lawson et al. 2014b), which may provide important subsidies of carbon and nutrients to the fjord microbial community throughout the melt season (Hood and Scott 2008; Bhatia et al. 2013; Lawson et al. 2014a). We designed this study to test this hypothesis-that bacteria are using allochthonous organic matter from glacier runoff as a source of organic carbon post bloom.

There are few estimates of freshwater runoff for Svalbard glaciers individually (Hagen et al. 2003), however one estimate from Kongsfjorden, which includes inputs from snowmelt, glacier melt, and freshwater from calved icebergs, reports the total runoff into this fjord system to be about $1.4 \mathrm{~km}^{3}$ annually (Svendsen et al. 2002). The total volume of Kongsfjorden is estimated to be $29.4 \mathrm{~km}^{3}$ (Ito and Kudoh 1997) of which approximately 5\% is derived from freshwater runoff. Dissolved organic carbon concentrations in the fjords were variable and ranged from $90 \mu \mathrm{mol} \mathrm{L}{ }^{-1}$ to $220 \mu \mathrm{mol} \mathrm{L}^{-1}$ across stations, which encompasses the range of previously measured DOC concentrations in Kongsfjorden (120-197 $\mu \mathrm{mol} \mathrm{L}{ }^{-1}$; Iversen and Seuthe 2011). Based on the maximum $\left(220 \mu \mathrm{mol} \mathrm{C} \mathrm{L}{ }^{-1}\right.$ or $\left.2366 \mu \mathrm{g} \mathrm{C} \mathrm{L}^{-1}\right)$ and minimum $(91 \mu \mathrm{mol}$ $\mathrm{C} \mathrm{L}^{-1}$ or $1093 \mu \mathrm{g} \mathrm{C} \mathrm{L}^{-1}$ ) organic carbon concentrations we measured in all fjord waters and assuming that $5 \%$ of the total volume of the fjord is derived from freshwater, we estimate that of the total DOC pool in Kongsfjord (3.2-7.8 $\times$ $\left.10^{10} \mathrm{gC}\right), 1.6-3.9 \times 10^{9} \mathrm{gC}$ should be derived from allochthonous carbon coming from the glaciers. Using the concentrations of DOC we measured in glacier runoff in this study, and the annual runoff into Kongsfjorden, we estimate the allochthonous carbon contribution to this fjord to be between 1.3 and $3.0 \times 10^{9} \mathrm{gC}$ annually. So, although the DOC concentrations we measured in the glacial runoff (Table 1) are lower than previous measurements of DOC in Svalbard glacial runoff ( $283 \mu \mathrm{mol} \mathrm{L}^{-1}$; Stibal et al. 2008), the carbon contribution of freshwater runoff into the fjord is still within the range we estimate using the total carbon pool. Assuming a bacterial carbon demand of $3.34 \mu \mathrm{gC} \mathrm{\textrm {L } ^ { - 1 }}$ $\mathrm{d}^{-1}$ as reported by Iversen and Seuthe (2011) for post-bloom conditions, the total carbon pool in the fjords $(1.1-2.3 \mathrm{mgC}$ $\mathrm{L}^{-1}$ ) appears to be sufficient to meet this demand, this is of course assuming that all carbon in the pool is labile.

To our knowledge no studies currently exist as to the bioavailability of DOC in Svalbard fjords or runoff from Svalbard glaciers, however one study in a fjord in Western Greenland found that $26-53 \%$ of the DOC in Greenland Ice Sheet runoff was bioavailable and mostly derived from microbial activity on the glacial surface (Lawson et al. $2014 b)$, although concentrations of DOC in ice sheet runoff (18-41 $\mu \mathrm{mol} \mathrm{L}^{-1}$ ) were much lower than those we measured in Svalbard glaciers. These findings are similar to the findings of Hood et al. (2009) in Alaskan glaciers (22-66\% bioavailable DOC). To the contrary, another study from Kobbefjord, West Greenland, found that bioavailable DOC in freshwater runoff was much lower than fjord concentrations where only 13-28\% of DOC in the fjord water was bioavailable, so that freshwater inputs led to a dilution rather than concentration of labile DOM, suggesting that the most likely source of DOC to marine heterotrophic bacteria in this fjord was from autochthonous marine photosynthetic production (Middelboe et al. 2012). The contrasting findings of these studies imply that bioavailability of DOC from different regions of the Arctic probably strongly depends on the source DOC to the runoff water and vegetation (or lack thereof) in the watershed.

Microbial and photoautotroph production in cryoconite holes is considered an important source of autochthonous carbon to the glacial surface (Lafrenière and Sharp 2004; Hodson et al. 2005)_indeed, our measurements of bacterial abundance confirm a significant microbial presence in glacial runoff water (Table 1)-however inputs from allochthonous wind-derived sources of carbon are considered to be more important to the total organic carbon pool in Svalbard glaciers (Stibal et al. 2008). DOC in sub-glacial runoff, however, can be derived from leaching of ancient soil which is consistently low in free carbohydrates and amino acids resulting in higher molecular weight organic carbon compared to the glacial surface (Lawson et al. 2014b). Organic matter low in aromatic carbon, such as that derived from microbial systems is thought to be more labile than that derived from higher plants (McKnight et al. 2001). Thus it will be important to characterize the type of runoff water or pool different types of runoff water to determine the bioavailability of organic carbon in freshwater entering the fjords.

In this study, we employed a direct method of determining whether organic carbon from glacial runoff was an important source of carbon to marine bacteria-by measuring the stable carbon isotopes of organic matter from both glacier runoff and autochthonous phytoplankton to determine the percent contribution of these possible sources of organic matter to the bacterial carbon isotope signature. As it is difficult to separate bacterial biomass from the plankton community, we measured carbon isotope signatures of polar lipid fatty acids in the plankton community, which allows us to distinguish between prokaryotic and eukaryotic cells of different phytoplankton groups (see Methods).

Samples of DOC from glacier runoff water were isotopically light, with an average value of $-28.5 \pm 0.9 \%$, suggesting much may have been derived from terrestrial primary production. One previous study quantified ${ }^{13} \mathrm{C}$ derived from runoff water from the Kongsbreen glacier as well as several other terrestrial runoff sources in the Kongsfjorden estuary and reported $\delta^{13} \mathrm{C}$-POC values ranging from $-25.1 \%$ to $-26.7 \%$ (Table 3; Kuliński et al. 2014). The $\delta^{13} \mathrm{C}$-POC values from terrestrial and glacier sources in Kongsfjorden from this previous study are somewhat higher than the DOC values for glacier runoff reported in this study, which may be attributed to either the type of melt water sampled (i.e., from 
surface melt, with higher contribution of microbial sourced carbon, vs. sub-glacial melt, which is influenced by leeching of ancient soils) or differences between carbon isotope values of POC vs. DOC. Nonetheless, the $\delta^{13} \mathrm{C}$-POC reported by Kuliński et al. (2014) and the $\delta^{13} \mathrm{C}$-DOC in this study are still much lower than the carbon isotope signature we measure for bacteria in the fjords $(-22.5 \pm 1.8 \%)$, indicating that organic carbon from glacier runoff is most likely not a contributor to the microbial food web in Svalbard fjords.

$\delta^{13} \mathrm{C}$ values of phytoplankton measured in this study were consistent with those reported for marine phytoplankton and marine POM elsewhere in the region (Table 3). However, $\delta^{13} \mathrm{C}$ POM was still significantly different than $\delta^{13} \mathrm{C}$ of bacteria (see Results), indicating that there was a third source of carbon alimenting bacterial communities in the fjord system. Given the enriched isotope signature of bacterial carbon, we performed a literature search to deduce other possible sources of carbon to bacteria in Svalbard fjords.

Several microbial carbon cycling models in the Arctic suggest that that zooplankton grazing may play an important role in providing missing organic carbon during the post bloom period (Møller and Nielsen 2000; Thingstad et al. 2002), however it has been reported that fecal matter from zooplankton are depleted $\mathrm{in}^{13} \mathrm{C}$ by $4.3-11.3 \%$ relative to autotrophic biomass (Klein Breteler et al. 2002; Tamelander et al. 2006b); we only located one study reporting ${ }^{13} \mathrm{C}$ values from Arctic zooplankton fecal pellets (Tamelander et al. $2006 b$ ), as DOC derived from fecal pellets is difficult to estimate, and because of the additional depletion in ${ }^{13} \mathrm{C}$, we have ruled it out as a possible source of organic carbon to heterotrophic bacteria in our study.

Literature values of ice algae and particulate organic matter from sea ice in the Barents Sea-Fram Strait region are, on average, enriched in ${ }^{13} \mathrm{C}$ (Table 3). Isotopically heavy ice algae compared to water column phytoplankton is a common phenomena in both the Arctic and Southern Ocean (e.g., Gibson et al. 1999) and is generally attributed to $\mathrm{CO}_{2}$ limitation of ice-algae, as intense photosynthetic activity in sea ice brines has been reported to lead to a more than twofold decrease in DIC concentrations (Gleitz et al. 1995). It has also been proposed that the enriched ${ }^{13} \mathrm{C}$ signature of ice algae may be due to their ability to directly take up bicarbonate, resulting in a signature closer to that of dissolved inorganic carbon (0-2\%; Mitchell and Beardall 1996).

Ice conditions in Svalbard fjords throughout the spring fluctuate from partial coverage to ice free conditions (Hodal et al. 2012). Sea ice formed in the fjords is mainly land fast and breaks up anywhere from April to July (Svendsen et al. 2002). The outer parts of the fjords can be covered with drift ice, ranging in concentration from $1 / 10$ to $8 / 10$ and originating either in situ or transported into the fjords via winds, currents, and tides (Svendsen et al. 2002). Ice algae are significant primary producers in the region contributing much of the annual primary production (Gosselin et al. 1997;
Gradinger 2009), and literature supports the importance of the release of organic matter trapped in ice as an important source of organic carbon to the microbial food web (Vézina et al. 1997; Giesenhagen et al. 1999); ice algal can also account for a large amount carbon export during the ice melt season (Boetius et al. 2013). Thus, we propose that ice algae could be a significant source of organic carbon to water column bacterial communities in the fjords throughout the summer.

Hence, we identify three sources of organic carbon available to support bacteria: (1) allochthonous organic carbon, delivered with glacier runoff and characterized as the isotopically lighter end member in the system; (2) phytoplankton, with intermediate $\delta^{13} \mathrm{C}$ values; and (3) ice algae with heavier $\delta^{13} \mathrm{C}$ values. Bacterial PLFAs were more enriched in $^{13} \mathrm{C}$ than glacial DOC and POC and PLFAs of phyto b (Fig. 4 ). $\Delta^{13} \mathrm{C}$ of POC in our study more closely aligned with $\delta^{13} \mathrm{C}$ of PLFAs of phyto $b$ and our "phytoplankton" end member (i.e., an average of phyto a and phyto b values) (Fig. 4). We gathered 16 literature values of $\delta^{13} \mathrm{C}$ of POM (Table 3), which averaged $( \pm \mathrm{SD})-24.5 \pm 2.2 \%$, more variable but not different than the average $\delta^{13} \mathrm{C}$ POC values we found in this study $(-24.4 \pm 1.7 \%, t=-0.10, p=0.92)$. Literature values of $\delta^{13} \mathrm{C}$ of ice algae and particulate organic matter from sea ice in the Barents Sea-Fram Strait region were, on average, slightly higher than $\delta^{13} \mathrm{C}$ of bacterial PLFAs, confirming their possible role as an end member supplying organic carbon to bacteria (Fig. 5). The $\delta^{13} \mathrm{C}$ of bacterial PLFAs was also negatively correlated to salinity (Fig. 2) and $\delta^{13} \mathrm{C}$ of bacteria in the open-ocean ice free station was less enriched in ${ }^{13} \mathrm{C}$ than in fjord stations (Table 2), implying that bacteria carbon is increasingly enriched in ${ }^{13} \mathrm{C}$ in fresher water masses. This is as expected if an important part of the source of organic carbon to bacteria comes from ice when melting releases both isotopically heavy ice algae-derived carbon and freshwater. Although paired $t$-tests did not indicate significant differences between surface and DCM layers for bacterial $\delta^{13} \mathrm{C}$ values, in all but one instance the DCM had slightly more depleted values of bacterial $\delta^{13} \mathrm{C}$ than surface waters. As surfaces waters are more exposed to sea-ice melt waters, this observation is also consistent with the role of ice algae as a significant source of carbon to marine bacteria.

When using PLFAs, however, it is important to consider the fractionation that takes place during fatty acid synthesis before applying any sort of mixing model (Middelburg 2014). A previous study reported $\delta^{13} \mathrm{C}$ of bulk tissue and the fatty acid C20:5 $\omega 3$ in both ice algae (Nitzschia frigida) and phytoplankton (Phaeocystis pouchetii and Thalassiosira hyaline) collected in May in the Barents Sea (Table 3; McMahon et al. 2006). McMahon et al. (2006) report that $\mathrm{C} 20: 5 \omega 3$ of phytoplankton $(-32.0 \pm 0.3 \%$ o $)$ was much more depleted in ${ }^{13} \mathrm{C}$ than $\mathrm{C} 20: 5 \omega 3$ of ice algae $(-21.9 \pm 0.4 \%$ ) and bulk tissue values were depleted in ${ }^{13} \mathrm{C}$ relative to the $\delta^{13} \mathrm{C}$ of $\mathrm{C} 20: 5 \omega 3$ in both phytoplankton and ice algae yielding values of 
$-24.5 \pm 0.5 \%$ and $-15.7 \pm 0.5 \%$ respectively (Table 3; McMahon et al. 2006). The difference between $\delta^{13} \mathrm{C}$ of C20:5 03 and bulk tissue is due to fractionation during fatty acid synthesis, which McMahon et al. (2006) report to be $7.5 \%$ and $6.2 \%$ for phytoplankton and ice algae respectively for the fatty acid C20:5 23 . This fractionation factor is slightly higher than the range of literature values of $2-5 \%$ (Boschker and Middelburg 2002; Middelburg 2014) we used to quantify fractionation during fatty acid synthesis in this study. However, there is evidence that isotopic fractionation in fatty acid synthesis may be much larger depending on the fatty acid ( $-4 \%$ to $8 \%$; Boschker et al. 1999). Regardless, the $\delta^{13} \mathrm{C}$ of $\mathrm{C} 20: 5 \omega 3$ in our POM samples ranged from $-21.1 \%$ to $-33.8 \%$ (Table 2) encompassing the value of $\mathrm{C} 20: 5 \omega 3$ reported by McMahon et al. (2006), although our mean ( \pm $\mathrm{SD}$ ) value is much higher that study (Table $2 ;-24.3 \pm 2.9 \%$ o vs. $-32.0 \pm 0.3 \%$ in McMahon et al. 2006). However, the bulk value of phytoplankton reported by McMahon et al. (2006) $(-24.5 \pm 0.5 \%$ ) was similar to the average $( \pm$ SD) value of POC reported in this study (Table $2 ;-24.4 \pm 1.7 \%$ ) and the corrected "phytoplankton" end member value we use in our mixing model $(-23.5 \pm 3.0 \%$ o $)$.

Fatty acid fractionation during synthesis can vary not only among organisms (as demonstrated by the differences in fractionation factor of phytoplankton vs. ice algae for the fatty acid C20:5 03 (McMahon et al. 2006)), but can also vary among fatty acids within the same organism. This has been extensively studied by Veefkind (2003) across several trophic levels-who reported a difference of up to $7 \%$ o among fatty acids in POM samples. Results from a study with algal monocultures showed that the fatty acids 18:3 $\omega 3$ and $18: 3 \omega 4$ (used in this study to estimate phyto b), and 20:5 $\omega 3$ and 22:6 $\omega 3$ (used in this study to estimate phyto a) differ by ca. $4 \%$ (Gladyshev et al. 2016). The variation in fractionation among different fatty acids during synthesis further supports our decision to average the two grouping as one phytoplankton end member. Attempting to resolve the error due to differences in individual fatty acid fractionation factors would unnecessarily complicate the analysis and distract from the main object of the study.

In order to account for all three sources of organic carbon and their variation, as well as the fractionation factors and their associated variation we performed a Bayesian isotope mixing model, which has been used previously to account for multiple sources of variation in isotope mixing models (Parnell et al. 2010). The model rejected the hypothesis that allochthonous organic carbon is an important source of carbon for bacteria in the Svalbard fjord systems, as it accounted for only $10.8 \% \pm 7.2 \%$ of bacterial carbon incorporation. In contrast, ice algae emerged as the most important source of organic carbon to bacteria contributing $58.9 \% \pm 10.5 \%$ to the bacterial carbon isotope signature, compared to $30.3 \% \pm 14.7 \%$ contributed by phytoplankton.
To our knowledge, this is the first study that investigates the sources of organic carbon to bacteria in the Barents SeaFram Strait- Svalbard region and the first study reporting $\delta^{13} \mathrm{C}$ of bacteria anywhere in the Arctic Ocean, making our values the first of such reported. The identification of ice algae as a main source of organic carbon to bacteria is unexpected, as we had expected that in the only partially ice covered fjords, bacteria would mainly be using either water column phytoplankton or DOC from glacier runoff as their main carbon sources during the summer. Note however that, this study took place during June in a post bloom period and it is likely that bacterial carbon sources change throughout the growing season as the supply and availability of various organic carbon sources may also change. However, due to the low contribution of glacier DOC to the carbon signature of bacteria, it is unlikely that glacial runoff provides an important subsidy of carbon to bacterial communities post bloom. Regardless, the finding that bacteria use ice algae as a main source of carbon in Arctic fjords may have implications for bacterial metabolism in future scenarios of climate change, as sea ice algae liberated by sea ice melting will only increase in the future, providing an important subsidy of organic carbon throughout the summer and possibly tipping the annual budget of metabolic balance toward a dominance of heterotrophy.

Future predictions remain challenging however, due to the many unknowns associated with (1) bioavailability of other carbon sources throughout the growing season (2) the consequences of allochthonous nutrient inputs (e.g., Lawson et al. 2014a) that may affect the metabolic balance, and (3) rising Arctic temperatures that also influence plankton metabolism, possibly doubling community respiration (VaquerSunyer et al. 2010; Holding et al. 2013). Since bacteria in polar waters are limited by organic carbon (Møller and Nielsen 2000; Pomeroy and Wiebe 2001; Thingstad et al. 2002; Kritzberg et al. 2010) it is important to accurately quantify possible changes in organic carbon supply to the system.

The limited role of allochthonous organic carbon inputs to bacterial biomass in Svalbard fjords is consistent with results from Greenland fjords (Middelboe et al. 2012) and may derive from the combination of limited supply and availability of this organic carbon source from certain types of glacial runoff, but our results are in contrast with studies from Alaskan glaciers and the Greenland Ice Sheet (Hood et al. 2009; Lawson et al. 2014b) reporting a quite high bioavailability of organic carbon in runoff. Since our study, however, focuses on the direct measurements in situ of bacterial usage of carbon from various sources using stable isotopes, the conclusions are more direct and thus more robust. Notwithstanding, in this study we focused on carbon that bacteria incorporate as biomass, whereas a recent study suggests that bacteria may selectively allocate terrestrial and autochthonous derived carbon separately for respiration and biomass synthesis (Guillemette et al. 2015), which could 
explain the discrepancy between the conclusions in our study vs. the previous studies which show high bioavailability of DOC in glacier run-off. Nonetheless, dissolved organic carbon concentrations in glacier runoff waters were not consistently elevated relative to DOC in fjord waters or the open-sea, suggesting that, at least in Svalbard fjords, glacial inputs do not necessarily lead to elevated DOC levels, as indicated by lack of a significant relationship between DOC and salinity in the system studied. Our results identify ice algae as a major source of carbon to the microbial food web in the Svalbard fjord system. Hence, resolving how ice algae may respond to climate warming-induced changes in ice cover and ice duration is of fundamental importance to ascertain the future responses of microbial food webs and Arctic plankton metabolism to climate change.

\section{References}

Abraham, W., C. Hesse, and O. Pelz. 1998. Ratios of carbon isotopes in microbial lipids as an indicator of substrate usage. Appl. Environ. Microbiol. 64: 4202-4209.

Arrigo, K. R., G. van Dijken, and S. Pabi. 2008. Impact of a shrinking Arctic ice cover on marine primary production. Geophys. Res. Lett. 35: 1-6. doi:10.1029/2008GL035028

Bhatia, M. P., E. B. Kujawinski, S. B. Das, C. F. Breier, P. B. Henderson, and M. A. Charette. 2013. Greenland meltwater as a significant and potentially bioavailable source of iron to the ocean. Nat. Geosci. 6: 274-278. doi:10.1038/ ngeo1746

Bligh, E. G., and W. J. Dyer. 1959. A rapid method of total lipid extraction and purification. Can. J. Biochem. Physiol. 37: 911-917. doi:10.1139/o59-099

Boetius, A., and others. 2013. Export of algal biomass from the melting Arctic sea ice. Science 339: 1430-1432. doi: 10.1126/science. 1231346

Boschker, H. T. S., S. C. Nold, P. Wellsbury, D. Bos, W. de Graaf, R. Pel, R. J. Parkes, and T. E. Cappenberg. 1998. Direct linking of microbial populations to specific biogeochemical processes by 13C-labelling of biomarkers. Nature 392: 801-805. doi:10.1038/33900

Boschker, H. T. S., J. F. C. De Brouwer, and T. E. Cappenberg. 1999. The contribution of macrophytederived organic matter to microbial biomass in salt-marsh sediments: Stable carbon isotope analysis of microbial biomarkers. Limnol. Oceanogr. 44: 309-319. doi:10.4319/ lo.1999.44.2.0309

Boschker, H. T. S., and J. J. Middelburg. 2002. Stable isotopes and biomarkers in microbial ecology. FEMS Microbiol. Ecol. 40: 85-95. doi:10.1111/j.1574-6941.2002.tb00940.x

Bouillon, S., and H. T. S. Boschker. 2006. Bacterial carbon sources in coastal sediments: A cross-system analysis based on stable isotope data of biomarkers. Biogeosciences 3: 175-185. doi:10.5194/bg-3-175-2006

de Kluijver, A., K. Soetaert, K. G. Schulz, U. Riebesell, R. G. J. Bellerby, and J. J. Middelburg. 2010. Phytoplankton- bacteria coupling under elevated CO2 levels: A stable isotope labelling study. Biogeosciences 7: 3783-3797. doi: 10.5194/bg-7-3783-2010

de Kluijver, A., K. Soetaert, J. Czerny, K. G. Schulz, T. Boxhammer, U. Riebesell, and J. J. Middelburg. 2013. A 13C labelling study on carbon fluxes in Arctic plankton communities under elevated $\mathrm{CO} 2$ levels. Biogeosciences 10: $1425-1440$. doi:10.5194/bg-10-1425-2013

Dietrich, G., K. Kalle, W. Krauss, and G. Siedler. 1980. General oceanography: An introduction, 2nd ed. Wiley-Interscience.

Dijkman, N. A., and J. C. Kromkamp. 2006. Phospholipidderived fatty acids as chemotaxonomic markers for phytoplankton: Application for inferring phytoplankton composition. Mar. Ecol. Prog. Ser. 324: 113-125. doi:10.3354/ meps324113

Dijkman, N. A., H. T. S. Boschker, J. J. Middelburg, and J. C. Kromkamp. 2009. Group-specific primary production based on stable-isotope labeling of phospholipid-derived fatty acids. Limnol. Oceanogr.: Methods 7: 612-625. doi: 10.4319/lom.2009.7.612

Duarte, C., and A. Regaudie-de-Gioux. 2009. Thresholds of gross primary production for the metabolic balance of marine planktonic communities. Limnol. Oceanogr. 54: 1015-1022. doi:10.4319/1o.2009.54.3.1015

Duarte, C. M., and others. 2012. Tipping elements in the Arctic marine ecosystem. Ambio 41: 44-55. doi:10.1007/ s13280-011-0224-7

Fellman, J. B., R. G. M. Spencer, P. J. Hernes, R. T. Edwards, D. V. D. Amore, and E. Hood. 2010. The impact of glacier runoff on the biodegradability and biochemical composition of terrigenous dissolved organic matter in near-shore marine ecosystems. Mar. Chem. 121: 112-122. doi: 10.1016/j.marchem.2010.03.009

Gibson, J. A. E., T. Trull, P. D. Nichols, R. E. Summons, and A. McMinn. 1999. Sedimentation of 13C-rich organic matter from Antarctic sea-ice algae: A potential indicator of past sea-ice extent. Geology 27: 331-334. doi:10.1130/ 0091-7613(1999)027 < 0331:SOCROM > 2.3.CO;2

Giesenhagen, H. C., A. E. Detmer, J. de Wall, A. Weber, R. R. Gradinger, and F. J. Jochem. 1999. How are Antarctic planktonic microbial foodwebs and algal blooms affected by metling of sea ice? Microcosm simulations. Aquat. Microb. Ecol. 20: 183-201. doi:10.3354/ame020183

Gladyshev, M. I., O. N. Makhutova, E. S. Kravchuk, O. V. Anishchenko, and N. N. Sushchik. 2016. Stable isotope fractionation of fatty acids of Daphnia fed laboratory cultures of microalgae. Limnologica 56: 23-29. doi:10.1016/ j.limno.2015.12.001

Gleitz, M., M. R. v.d. Loeff, D. N. Thomas, G. S. Dieckmann, and F. J. Millero. 1995. Comparison of summer and winter inorganic carbon, oxygen and nutrient concentrations in Antarctic sea ice brine. Mar. Chem. 51: 81-91. doi: 10.1016/0304-4203(95)00053-T

Gosselin, M., M. Levasseur, P. A. Wheeler, R. A. Horner, and B. C. Booth. 1997. New measurements of phytoplankton and 
ice algal production in the Arctic Ocean. Deep-Sea Res. Part II 44: 1623-1644. doi:10.1016/S0967-0645(97)00054-4

Gradinger, R. 2009. Sea-ice algae: Major contributors to primary production and algal biomass in the Chukchi and Beaufort Seas during May/June 2002. Deep-Sea Res. Part II 56: 1201-1212. doi:10.1016/j.dsr2.2008.10.016

Guillemette, F., S. L. McCallister, and P. A. del Giorgio. 2015. Selective consumption and metabolic allocation of terrestrial and algal carbon determine allochthony in lake bacteria. ISME J. 10: 1373-1382. doi:10.1038/ismej.2015.215

Hagen, J. O., J. Kohler, K. Melvold, and J. G. Winther. 2003. Glaciers in Svalbard: Mass balance, run-off, and freshwater flux. Polar Res. 22: 145-159. doi:10.1111/j.17518369.2003.tb00104.x

Hansen, H. P., and F. Koroleff. 1999. Determination of nutrients. In K. Grasshoff, K. Kremling, and M. Ehrhardt [eds.], Methods of seawater analysis. Wiley-VCH Verlag $\mathrm{GmbH}$.

Hodal, H., S. Falk-Petersen, H. Hop, S. Kristiansen, and M. Reigstad. 2012. Spring bloom dynamics in Kongsfjorden, Svalbard: Nutrients, phytoplankton, protozoans and primary production. Polar Biol. 35: 191-203. doi:10.1007/ s00300-011-1053-7

Hodson, A. J., P. N. Mumford, J. Kohler, and P. M. Wynn. 2005. The High Arctic glacial ecosystem: New insights from nutrient budgets. Biogeochemistry 72: 233-256. doi: 10.1007/s10533-004-0362-0

Hoegh-Guldberg, O., R. Cai, E. S. Poloczanska, P. G. Brewer, S. Sundby, K. Hilmi, V. J. Fabry, and S. Jung. 2014. The ocean, p. 1655-1731. In V. R. Barros and others [eds.], Climate change 2014: Impacts, adaptation, and vulnerability. Part B: Regional aspects. Contribution of Working Group II to the Fifth Assessment Report of the Intergovernmental Panel on Climate Change. Cambridge Univ. Press.

Holding, J. M., C. M. Duarte, J. M. Arrieta, R. Vaquer-Sunyer, P. Wassmann, and S. Agustí. 2013. Experimentally determined temperature thresholds for Arctic plankton community metabolism. Biogeosciences 10: 357-370. doi: 10.5194/bg-10-357-2013

Hood, E., and D. Scott. 2008. Riverine organic matter and nutrients in southeast Alaska affected by glacial coverage. Nat. Geosci. 1: 583-587. doi:10.1038/ngeo280

Hood, E., J. Fellman, R. G. M. Spencer, P. J. Hernes, R. Edwards, D. D'Amore, and D. Scott. 2009. Glaciers as a source of ancient and labile organic matter to the marine environment. Nature 462: 1044-1047. doi:10.1038/nature08580

Ingvaldsen, R., and H. Loeng. 2009. Physical oceanography, p. 33-64. In E. Sakshaug, G. Johnsen, and K. Kovacs [eds.], Ecosystem Barents Sea. Tapir Academics Press.

Ito, H., and S. Kudoh. 1997. Characteristics of water in Kongsfjorden, Svalbard, v. 11, p. 211-232. In Proceedings of the NIPR Symposium on Polar Meteorology and Glaciology.

Iversen, K. R., and L. Seuthe. 2011. Seasonal microbial processes in a high-latitude fjord (Kongsfjorden, Svalbard): I.
Heterotrophic bacteria, picoplankton and nanoflagellates. Polar Biol. 34: 731-749. doi:10.1007/s00300-010-0929-2

Klein Breteler, W. C. M., K. Grice, S. Schouten, H. T. Kloosterhuis, and J. S. Sinninghe Damsté. 2002. Stable carbon isotope fractionation in the marine copepod Temora longicornis: Unexpectedly low $\delta 13 \mathrm{C}$ value of faecal pellets. Mar. Ecol. Prog. Ser. 240: 195-204. doi: 10.3354/meps240195

Kritzberg, E. S., C. M. Duarte, and P. Wassmann. 2010. Changes in Arctic marine bacterial carbon metabolism in response to increasing temperature. Polar Biol. 33: 16731682. doi:10.1007/s00300-010-0799-7

Kuliński, K., M. Kędra, J. Legeżyńska, M. Gluchowska, and A. Zaborska. 2014. Particulate organic matter sinks and sources in high Arctic fjord. J. Mar. Syst. 139: 27-37. doi: 10.1016/j.jmarsys.2014.04.018

Lafrenière, M. J., and M. J. Sharp. 2004. The concentration and fluorescence of dissolved organic carbon (DOC) in glacial and nonglacial catchments: Interpreting hydrological flow routing and DOC sources. Arct. Antarct. Alp. Res. 36: 156-165. doi:10.1657/1523-0430(2004)036[0156:TCAFOD]2.0.CO;2

Lawson, E. C., M. P. Bhatia, J. L. Wadham, and E. B. Kujawinski. 2014a. Continuous summer export of nitrogenrich organic matter from the Greenland Ice Sheet inferred by ultrahigh resolution mass spectrometry. Environ. Sci. Technol. 48: 14248-14257. doi:10.1021/es501732h

Lawson, E. C., and others. 2014b. Greenland Ice Sheet exports labile organic carbon to the Arctic oceans. Biogeosciences 11: 4015-4028. doi:10.5194/bg-11-4015-2014

Leu, E., J. Wiktor, J. E. Søreide, J. Berge, and S. Falk-Petersen. 2010. Increased irradiance reduces food quality of sea ice algae. Mar. Ecol. Prog. Ser. 411: 49-60. doi:10.3354/meps08647

Loeng, H., and others. 2005. Marine systems, p. 453-538. In C. Symon [ed.], Arctic climate impacts ssessment. Cambridge Univ. Press.

McKnight, D. M., E. W. Boyer, P. K. Westerhoff, P. T. Doran, T. Kulbe, and D. T. Andersen. 2001. Spectrofluorometric characterization of dissolved organic matter for indication of precursor organic material and aromaticity. Limnol. Oceanogr. 46: 38-48. doi:10.4319/lo.2001.46.1.0038

McMahon, K. W., W. G. J. Ambrose, B. J. Johnson, M. Sun, G. R. Lopez, L. M. Clough, and M. L. Carroll. 2006. Benthic community response to ice algae and phytoplankton in Ny Ålesund, Svalbard. Mar. Ecol. Prog. Ser. 310: 1-14. doi:10.3354/meps310001

Middelboe, M., R. N. Glud, and M. K. Sejr. 2012. Bacterial carbon cycling in a subarctic fjord: A seasonal study on microbial activity, growth efficiency, and virus-induced mortality in Kobbefjord, Greenland. Limnol. Oceanogr. 57: 1732-1742. doi:10.4319/lo.2012.57.6.1732

Middelburg, J. J. 2014. Stable isotopes dissect aquatic food webs from the top to the bottom. Biogeosciences 11: 2357-2371. doi:10.5194/bg-11-2357-2014 
Middelburg, J. J., C. Barranguet, H. T. S. Boschker, P. M. T. Herman, T. Moens, and C. H. R. Heip. 2000. The fate of intertidal microphytobenthos carbon: An in situ 13Clabeling study. Limnol. Oceanogr. 45: 1224-1234. doi: 10.4319/lo.2000.45.6.1224

Mitchell, C., and J. Beardall. 1996. Inorganic carbon uptake by an Antarctic sea-ice diatom, Nitzschia frigida. Polar Biol. 16: 95-99. doi:10.1007/s003000050033

Møller, E. F., and T. G. Nielsen. 2000. Plankton community structure and carbon cycling off the western coast of Greenland, with emphasis on sources of DOM for the bacterial community. Aquat. Microb. Ecol. 22: 13-25. doi: 10.3354/ame022013

Pabi, S., G. L. van Dijken, and K. R. Arrigo. 2008. Primary production in the Arctic Ocean, 1998-2006. J. Geophys. Res. 113: 1-22. doi:10.1029/2007JC004578

Parnell, A., R. Inger, S. Bearhop, and A. L. Jackson. 2008. SIAR: Stable isotope analysis in R.

Parnell, A. C., R. Inger, S. Bearhop, and A. L. Jackson. 2010. Source partitioning using stable isotopes: Coping with too much variation. PloS One 5: e9672. doi:10.1371/ journal.pone.0009672

Parsons, T. R., Y. Maita, and C. M. Lalli. 1984. A manual of chemical and biological methods for seawater analysis. Pergamon Press.

Piwosz, K., W. Walkusz, R. Hapter, P. Wieczorek, H. Hop, and J. Wiktor. 2009. Comparison of productivity and phytoplankton in a warm (Kongsfjorden) and a cold (Hornsund) Spitsbergen fjord in mid-summer 2002. Polar Biol. 32: 549-559. doi:10.1007/s00300-008-0549-2

Pomeroy, L. R., and W. J. Wiebe. 2001. Temperature and substrates as interactive limiting factors for marine heterotrophic bacteria. Aquat. Microb. Ecol. 23: 187-204. doi: 10.3354/ame023187

Porter, K. G., and Y. S. Feig. 1980. The use of DAPI for identifying and counting aquatic microfloral. Limnol. Oceanogr. 25: 943-948. doi:10.4319/lo.1980.25.5.0943

R Core Team. 2014. A language and environment for statistical computing.

Raymond, P. A., and J. E. Bauer. 2001. Use of 14C and 13C natural abundances for evaluating riverine, estuarine, and coastal DOC and POC sources and cycling: A review and synthesis. Org. Geochem. 32: 469-485. doi:10.1016/ S0146-6380(00)00190-X

Raymond, P. A., and others. 2007. Flux and age of dissolved organic carbon exported to the Arctic Ocean: A carbon isotopic study of the five largest arctic rivers. Global Biogeochem. Cycles 21: 1-9. doi:10.1029/ 2007GB002934

Schubert, C. J., and S. E. Calvert. 2001. Nitrogen and carbon isotopic composition of marine and terrestrial organic matter in Arctic Ocean sediments: Implications for nutrient utilization and organic matter composition. Deep-Sea Res. Part I 48: 789-810. doi:10.1016/S0967-0637(00)00069-8
Seuthe, L. 2011. Planktonic food webs in the Arctic Ocean: Structure and function in contrasting season and physical settings across Fram Strait. Univ. of Tromsø.

Sieracki, M. E., P. W. Johnson, and J. M. Sieburth. 1985. Detection, enumeration, and sizing of planktonic bacteria by image-analyzed epifluorescence microscopy. Appl. Environ. Microbiol. 49: 799-810.

Søreide, J. E., H. Hop, M. L. Carroll, S. Falk-Petersen, and E. N. Hegseth. 2006. Seasonal food web structures and sympagic-pelagic coupling in the European Arctic revealed by stable isotopes and a two-source food web model. Prog. Oceanogr. 71: 59-87. doi:10.1016/j.pocean. 2006.06.001

Spyres, G., M. Nimmo, P. J. Worsfold, E. P. Achterberg, and A. E. Miller. 2000. Determination of dissolved organic carbon in seawater using high temperature catalytic oxidation techniques. TrAC Trends Anal. Chem. 19: 498-506. doi:10.1016/S0165-9936(00)00022-4

Stibal, M., M. Tranter, L. G. Benning, and J. Rehák. 2008. Brief report Microbial primary production on an Arctic glacier is insignificant in comparison with allochthonous organic carbon input. Environ. Microbiol. 10: 2172-2178. doi:10.1111/j.1462-2920.2008.01620.x

Svendsen, H., and others. 2002. The physical environment of Kongsfjorden-Krossfjorden, an Arctic fjord system in Svalbard. Polar Res. 21: 133-166. doi:10.1111/j.17518369.2002.tb00072.x

Taipale, S. J., E. Peltomaa, M. Hiltunen, R. I. Jones, M. W. Hahn, C. Biasi, and M. T. Brett. 2015. Inferring phytoplankton, terrestrial plant and bacteria bulk delta-13C values from compound specific analyses of lipids and fatty acids. PloS One 10: 1-19. doi:10.1371/journal.pone.0133974

Tamelander, T., P. E. Renaud, H. Hop, M. L. Carroll, W. G. Ambrose, and K. A. Hobson. 2006a. Trophic relationships and pelagic--benthic coupling during summer in the Barents Sea Marginal Ice Zone, revealed by stable carbon and nitrogen isotope measurements. Mar. Ecol. Prog. Ser. 310: $33-46$. doi: $10.3354 /$ meps 310033

Tamelander, T., J. E. Søreide, H. Hop, and M. L. Carroll. $2006 b$. Fractionation of stable isotopes in the Arctic marine copepod Calanus glacialis: Effects on the isotopic composition of marine particulate organic matter. J. Exp. Mar. Biol. Ecol. 333: 231-240. doi:10.1016/j.jembe.2006.01.001

Tamelander, T., C. Kivimäe, R. G. J. Bellerby, P. E. Renaud, and S. Kristiansen. 2009. Base-line variations in stable isotope values in an Arctic marine ecosystem: Effects of carbon and nitrogen uptake by phytoplankton. Hydrobiologia 630: 63-73. doi:10.1007/s10750-009-9780-2

Thingstad, T., T. Nielsen, A. Skjoldborg Hansen, and $\mathrm{H}$. Levinsen. 2002. Control of bacterial production in cold waters. A theoretical analysis of mechanisms relating bacterial production and zooplankton biomass in Disko Bay, Western Greenland. Mar. Ecol. Prog. Ser. 228: 15-24. doi: 10.3354/meps228015 
Van den Meersche, K., P. Van Rijswijk, K. Soetaert, and J. J. Middelburg. 2009. Autochthonous and allochthonous contributions to mesozooplankton diet in a tidal river and estuary: Integrating carbon isotope and fatty acid constraints. Limnol. Oceanogr. 54: 62-74. doi:10.4319/ lo.2009.54.1.0062

Vaquer-Sunyer, R., C. M. Duarte, R. Santiago, P. Wassmann, and M. Reigstad. 2010. Experimental evaluation of planktonic respiration response to warming in the European Arctic Sector. Polar Biol. 33: 1661-1671. doi:10.1007/ s00300-010-0788-x

Vaquer-Sunyer, R., C. M. Duarte, J. M. Holding, A. Regaudiede-Gioux, L. S. García-Corral, M. Reigstad, and P. Wassmann. 2013. Seasonal patterns in Arctic planktonic metabolism (Fram Strait - Svalbard region). Biogeosciences 10: 1451-1469. doi:10.5194/bg-10-2347-2013

Veefkind, R. J. 2003. Carbon isotope ratios and composition of fatty acids: Tags and trophic markers in pelagic organisms. Univ. of Victoria.

Vézina, A. F., S. Demers, I. Laurion, T. Sime-Ngando, S. Kim Juniper, and L. Devine. 1997. Carbon flows through the microbial food web of first-year ice in resolute passage (Canadian High Arctic). J. Mar. Syst. 11: 173-189. doi: 10.1016/S0924-7963(96)00037-1

Viso, A. C., and J. C. Marty. 1993. Fatty acids from 28 marine microalgae. Phytochemistry 34: 1521-1533. doi: 10.1016/S0031-9422(00)90839-2
Wang, G., C. Guo, W. Luo, M. Cai, and J. He. 2009. The distribution of picoplankton and nanoplankton in Kongsfjorden, Svalbard during late summer 2006. Polar Biol. 32: 1233-1238. doi:10.1007/s00300-009-0666-6

Wassmann, P., J. Carroll, and R. Bellerby. 2008. Carbon flux and ecosystem feedback in the northern Barents Sea in an era of climate change: An introduction. Deep-Sea Res. Part II 55: 2143-2153. doi:10.1016/j.dsr2.2008.05.025

\section{Acknowledgments}

We thank the captain and crew of the R/V Helmer Hanssen, J.C. Alonso for nutrient measurements, A. Dorsett for assistance with DOC measurements, Pieter van Rijswijk and Peter van Breugel for assistance with PLFA analysis and measurements, the Royal Netherlands Institute for Sea research (NIOZ) in Yerseke for accommodation, laboratory space, and technical support, and D. van Oevelen for coordinating analyses at NIOZ. This research was supported by the ARCTICMED project funded by the Spanish Ministry of Economy and Inovation (ref. CTM201115792-E) and the Netherlands Earth System Science Center. J.H. was supported by a JAE fellowship (CSIC, Spain).

\section{Conflict of Interest}

None declared.
Submitted 22 June 2016 Revised 07 December 2016 Accepted 04 January 2017

Associate editor: Thomas Anderson 